\title{
A checklist of the reptiles and amphibians found in protected areas along the South African Wild Coast, with notes on conservation implications
}

\begin{tabular}{|c|c|}
\hline \multicolumn{2}{|c|}{$\begin{array}{l}\text { Authors: } \\
\text { Jan A. Venter }{ }^{1} \\
\text { Werner Conradie }^{2,3}\end{array}$} \\
\hline \multicolumn{2}{|c|}{$\begin{array}{l}\text { Affiliations: } \\
{ }^{1} \text { School of Natural Resource } \\
\text { Management, Nelson } \\
\text { Mandela Metropolitan } \\
\text { University, George Campus, } \\
\text { South Africa }\end{array}$} \\
\hline \multicolumn{2}{|c|}{$\begin{array}{l}\text { 2Port Elizabeth Museum } \\
\text { (Bayworld), Port Elizabeth, } \\
\text { South Africa }\end{array}$} \\
\hline \multicolumn{2}{|c|}{$\begin{array}{l}{ }^{3} \text { South African Institute } \\
\text { for Aquatic Biodiversity, } \\
\text { Grahamstown, South Africa }\end{array}$} \\
\hline \multicolumn{2}{|c|}{$\begin{array}{l}\text { Correspondence to: } \\
\text { Jan Venter }\end{array}$} \\
\hline \multicolumn{2}{|c|}{$\begin{array}{l}\text { Email: } \\
\text { jan.venter@nmmu.ac.za }\end{array}$} \\
\hline \multicolumn{2}{|c|}{$\begin{array}{l}\text { Postal address: } \\
\text { Private Bag X6531, G } \\
6530 \text {, South Africa }\end{array}$} \\
\hline \multicolumn{2}{|c|}{$\begin{array}{l}\text { Dates: } \\
\text { Received: } 24 \text { Nov. } 2014 \\
\text { Accepted: } 27 \text { May } 2015 \\
\text { Published: } 17 \text { Nov. } 2015\end{array}$} \\
\hline \multicolumn{2}{|c|}{$\begin{array}{l}\text { How to cite this article: } \\
\text { Venter, J.A. \& Conradie, W., } \\
2015, \text { 'A checklist of the } \\
\text { reptiles and amphibians } \\
\text { found in protected areas } \\
\text { along the South African } \\
\text { Wild Coast, with notes on } \\
\text { conservation implications', } \\
\text { Koedoe } 57(1) \text {, Art. \#1247, } \\
25 \text { pages. http://dx.doi. } \\
\text { org/10.4102/koedoe. } \\
\text { v57i1.1247 }\end{array}$} \\
\hline \multicolumn{2}{|c|}{$\begin{array}{l}\text { Copyright: } \\
\text { (C) 2015. The Authors. } \\
\text { Licensee: AOSIS } \\
\text { OpenJournals. This work is } \\
\text { licensed under the Creative } \\
\text { Commons Attribution } \\
\text { License. }\end{array}$} \\
\hline \multicolumn{2}{|l|}{ Read online: } \\
\hline 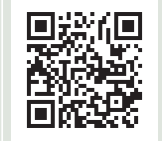 & $\begin{array}{l}\text { Scan this QR } \\
\text { code with your } \\
\text { smart phone or } \\
\text { mobile device } \\
\text { to read online. }\end{array}$ \\
\hline
\end{tabular}

Authors:

Jan A. Venter

Affiliations:

${ }^{1}$ School of Natural Resource

Management, Nelson

Mandela Metropolitan

University, George Campus,

(Bayworld), Port Elizabeth

for Aquatic Biodiversity,

Correspondence to:

Jan Venter

Email:

Postal address:

Private Bag X6531, George

Dates:

Received: 24 Nov. 2014

Accepted: 27 May 2015

How to cite this article: Venter, J.A. \& Conradie, W. 2015, 'A checklist of the along the South African Wild Coast, with notes on conservation implications' Koedoe 57(1), Art. \#1247,

25 pages. http://dx.doi. org/10.4102/koedoe. v57i1.1247

Copyrigh

Licensee: AOSIS

OpenJournals. This work is licensed under the Creative Commons Attribution License. to read online.
We surveyed six protected areas along the Wild Coast of the Eastern Cape, South Africa, to determine general herpetofaunal diversity as well as the representation of species of special conservation concern. Visual encounter survey methods and standard Y-shape trap arrays were used to conduct surveys from 2011 to 2013. A total of 59 species (22 amphibians and 37 reptiles) were recorded. A number of previously unknown populations of threatened species and one potential novel species were discovered in these protected areas, and the known ranges of several other species were extended. A total of 243 quarter-degree grid-cell unit records were documented, of which 90 (23\% amphibians and 50\% reptiles) represented the first records for the area. Amphibian and reptile diversity increased along the coast and a number of species of conservation concern were well represented in current protected areas. Our study provides a comprehensive amphibian and reptile checklist for an under-sampled region and highlights the importance of baseline data for improving conservation management.

Conservation implications: Small protected areas play an important role in conserving a number of threatened herpetofaunal species along the Wild Coast. The region is currently under significant and increasing pressure from anthropogenic-induced environmental degradation, which affects biodiversity and subsequently the local inhabitants. The information presented here represents an important baseline for future conservation management.

\section{Introduction}

Amphibians and reptiles are declining globally owing to habitat loss and degradation, pressure from alien invasive species, environmental pollution, disease, unsustainable use and global climate change (Böhm et al. 2013). Protected areas are often useful tools for the protection of herpetofauna and contribute to the conservation of many species (Ochoa-Ochoa et al. 2009; Tuberville et al. 2005). Management actions within protected areas may, however, have a significant impact on herpetofaunal ecology in a number of ways (Measey, Armstrong \& Hanekom 2009; Russell, Lear \& Guynn Jr. 1999). It is therefore critical that protected area managers consider herpetofaunal diversity, abundance and distributions within a local and regional context in conservation management.

Southern Africa, the geographical region south of the Cunene and Zambezi rivers, has the richest reptile diversity in Africa (Branch 2006). Within this area, South Africa (including Lesotho and Swaziland) has the highest reptile diversity (384 indigenous species) (Branch 2014). The Wild Coast, in the former Transkei ('Transkei' refers to a former homeland in pre-democratic South Africa), is regarded as having very low reptile diversity compared with southern and northeastern areas of South Africa (Branch 2014). Although the Pondoland region of the Wild Coast (eastern coastal region of the Eastern Cape, South Africa) is regarded as a centre of high plant diversity and endemism (Van Wyk \& Smith 2001), the terrestrial faunal species of the entire Wild Coast region (coastal Transkei and Pondoland combined), in many cases, remain poorly represented compared with other areas in southern Africa (Bates et al. 2014; Dippenaar, Hamer \& Haddad 2011; Minter et al. 2004; Mokhatla et al. 2012; Perera, Ratnayake-Perera \& Proches 2011; Skead 2007). Most herpetological studies from this area date back to the early 1900s (FitzSimons 1930; Power 1935), with only a few recent ad hoc surveys added (Branch \& Haagner 1999; Burger 1996; Haagner 1994). This could possibly be attributed to the remoteness of the area and unfavourable road conditions, as well as perceived safety risks, which made the logistics of field sampling challenging and, in turn, may have deterred herpetologists from working in the area. Some authors go as far as to describe the phenomenon as the 'Transkei faunal distribution gap'; that is a real gap in species distributions caused by environmental features (Botts, Erasmus \& Alexander 2011; Perera et al. 2011; Skead 2007; C. Vernon pers. comm., 13 November 2013). This perceived distribution gap is observed for many reptile species, particularly chelonians 
(Bates et al. 2014; Branch, Benn \& Lombard 1995). There are several examples of currently known reptile species distributions (e.g. for Trachylepis capensis, Bitis arietans and Lamprophis aurora) extending all the way to the Kei River along the east coast, with a gap in distribution through the coastal Transkei-Pondoland region, and afterwards extending further north along the KwaZulu-Natal coastline (Bates et al. 2014; Minter et al. 2004).

The lack of herpetofaunal records along the Wild Coast is a biodiversity conservation concern. It is not clear whether the current conservation initiatives in the Wild Coast region, which forms part of the larger Maputaland-PondolandAlbany Global Biodiversity Hotspot (Mittermeier et al. 2004), are sufficient for protecting herpetofauna. This relates specifically to species of special conservation concern, as well as to providing a sufficient north-east to south-west corridor for species dispersal. In addition, the resulting lack of knowledge increases the risk of negative impacts on amphibian and reptile species through poor management and development.

The objectives of this study were (1) to provide an annotated list of amphibians and reptiles occurring in protected areas along the Wild Coast and (2) to assess representation of species of special conservation concern (threatened and endemic species) in relevant protected areas.

\section{Study areas}

We surveyed a total of six protected areas along the Wild Coast in the Eastern Cape province, South Africa, from 2011 to 2013 (Figure 1). The area that constitutes the 'Wild Coast' stretches from north-east of East London to the KwaZuluNatal border and includes the former Transkei and the Pondoland regions. Protected areas comprise (from south to north) the Cape Morgan Nature Reserve, Manubi State Forest, Dwesa Nature Reserve, Hluleka Nature Reserve, Silaka Nature Reserve and Mkambati Nature Reserve.

\section{Cape Morgan Nature Reserve}

East London Coast Nature Reserves comprises a number of small nature reserves (NRs) and state forests (SFs) situated primarily along the coastline between the Great Kei River in the north and the Great Fish River in the south (Figure 1). The survey was conducted only in the Cape Morgan (214 ha) and Double-Mouth (199 ha) sections of this reserve. Vegetation types consist of southern Coastal Forest (low forests with a well-developed low tree and shrub component) (Mucina \& Geldenhuys 2006) and Albany Coastal Belt Grassland

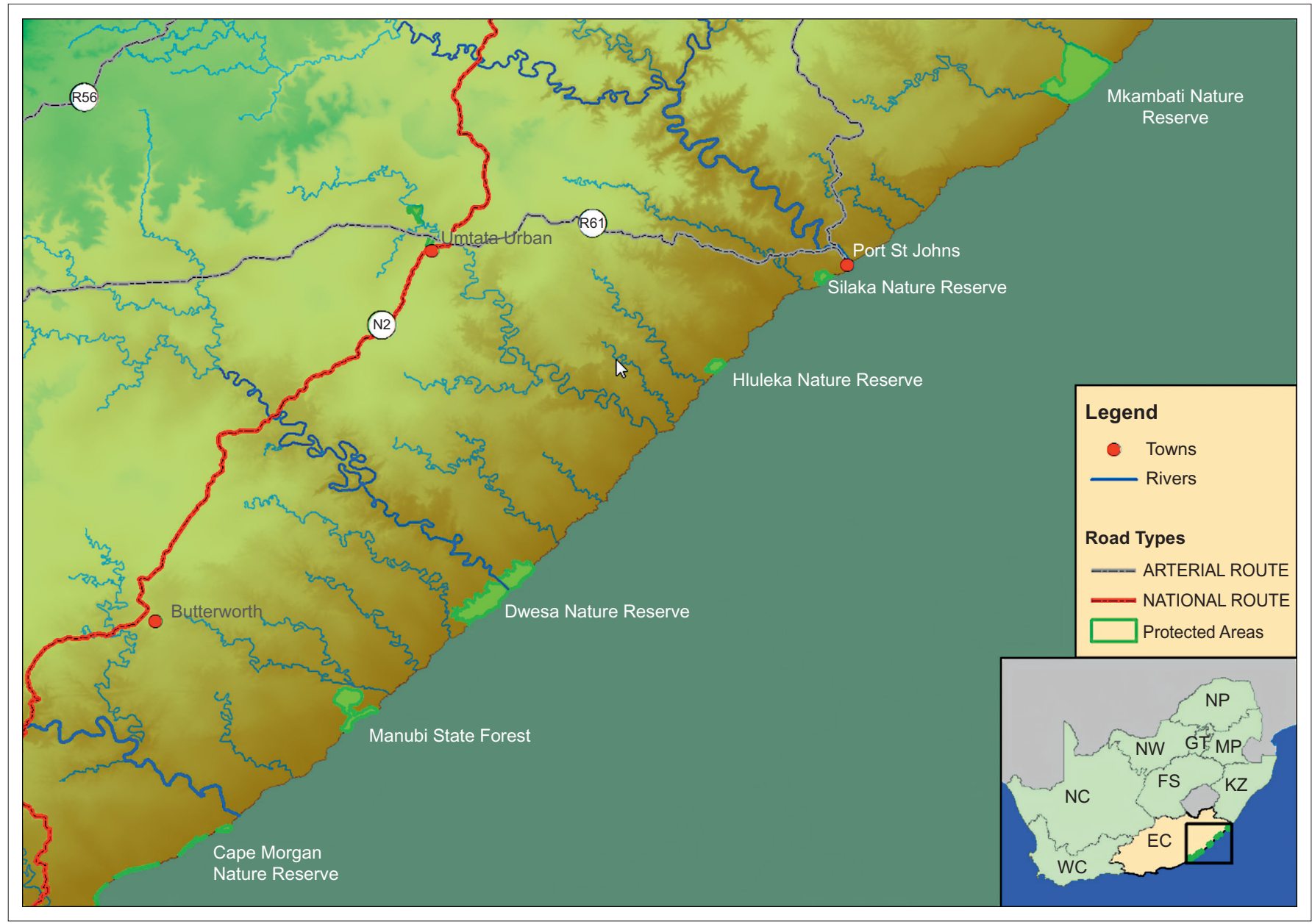

Source: Sherwyn Mack, Eastern Cape Parks and Tourism Agency

FIGURE 1: The location of the six protected areas along the Wild Coast, Eastern Cape, South Africa, where reptile and amphibian surveys were conducted. 
(Hoare et al. 2006). The survey was conducted from 26 March to 02 April 2012 (Venter \& Conradie 2012a).

\section{Manubi State Forest}

The Manubi SF (with an adjacent proposed expansion area) is located in the south-western part of the Wild Coast, southeast of the town Butterworth (Figure 1). Manubi SF and the adjacent area contain small patches of subtropical dune thicket, but are dominated by Scarp forest and Transkei Coastal Belt vegetation types (Mucina \& Geldenhuys 2006; Mucina et al. 2006). The survey was conducted from 18 to 27 February 2013 (Venter et al. 2013).

\section{Dwesa Nature Reserve}

The Dwesa NR (3623 ha) is located along the western side of the Mbashe River estuary (Figure 1). The reserve occupies a narrow coastal strip of approximately $9 \mathrm{~km}$ in length and $1 \mathrm{~km}-2 \mathrm{~km}$ in width. Dwesa NR comprises roughly $80 \%$ indigenous coastal Scarp forest and 20\% Transkei Coastal Belt Grassland (Mucina \& Geldenhuys 2006; Mucina et al. 2006). Dune forest and scrub forest are also found close to the coast and are classified as sensitive vegetation types (Mucina et al. 2006). The survey was conducted from 05 to 15 February 2012 (Venter \& Conradie 2012b).

\section{Hluleka Nature Reserve}

The Hluleka NR (577 ha) is situated nearly in the centre of the Wild Coast (Figure 1), south-west of Port St Johns along the coast. Scarp forest and coastal forest cover approximately $70 \%$ of the reserve, whereas the remainder of the vegetation is made up of thicket and Transkei Coastal Belt Grassland (Mucina \& Geldenhuys 2006; Mucina et al. 2006). The survey was conducted from 20 to 28 October 2011 (Venter \& Conradie 2012c).

\section{Silaka Nature Reserve}

Silaka NR is a small (400 ha) protected area situated southwest of Port St Johns (Figure 1). It is made up mainly of a forested valley located between Second Beach and Sugar Loaf Rock. Vegetation types include Transkei Coastal Belt Grassland (Mucina et al. 2006) and Scarp forest (Mucina \& Geldenhuys 2006). The survey was conducted from 29 September to 06 October 2012 (Venter, Conradie \& Greeff 2012).

\section{Mkambati Nature Reserve}

Mkambati NR (7736 ha) is situated along the north-eastern Pondoland coast (Figure 1). The vegetation types are dominated by fire-prone Pondoland Ugu Sandstone Coastal Sourveld with patches of Scarp and Swamp forest in fire refuge areas (Mucina \& Geldenhuys 2006; Mucina et al. 2006). This reserve also contains a large population of wild ungulates (Venter et al. 2014). The survey was conducted from 07 to 13 February 2011 (Venter \& Conradie 2011).

\section{Material and methods}

We used a combination of visual encounter survey methods and standard Y-shape trap arrays. Each trap array consisted of three drift fences of $10 \mathrm{~m}$ long and $50 \mathrm{~cm}$ high, positioned in a Y-shape, with four pitfall traps at the ends and middle, and two one-way funnels per fence - see Appendix 4. Surveys of the six Wild Coast protected areas were conducted from 2011 to 2013. Diurnal searches were conducted by actively searching specific microhabitats, including beneath rocks and decaying logs. Nocturnal surveys were also carried out with the use of headlamps or flashlights, and advertisement calls were recorded in the field using either an Olympus VN-3500PC Voice Recorder or NAGRA ARES-ML recorder with an external Sony F-V4T microphone. All specimens other than voucher specimens were captured by hand or net (e.g. tadpoles), photographed and released back to the original capture site. Voucher specimens were humanely euthanised by injecting reptiles with and submerging amphibians in a tricaine methanesulfonate (MS222) solution (Conroy et al. 2009), after which they were fixed in formalin for 48 hours and transferred to $50 \%$ isopropanol for long-term storage in the herpetological collection of the Port Elizabeth Museum (PEM). Specimens were identified using field guides and publications (Branch 1998; Channing 2001; Channing \& Baptista 2013; Channing et al. 2013; Du Preez \& Curruthers 2009; Marais 2004; Petzold et al. 2014). Nomenclature was mainly based on Frost (2014) for amphibians and Uetz (2014) for reptiles, or updated taxonomy in recent journal publications (Channing \& Baptista 2013; Petzold et al. 2014). Conservation status is based on the latest IUCN assessments, which use updated evaluations for amphibians (Measey 2011) and reptiles (Bates et al. 2014). All fieldwork was supervised by the first author, who was a staff member of the Eastern Cape Parks and Tourism Agency at the time, and formed part of the agency's operational activities as the appointed management authority of the protected areas stipulated by the Eastern Cape Parks and Tourism Agency Act (no. 2 of 2010). Collection and handling of specimens was according to ethical standards of Bayworld/Port Elizabeth Museum (Bayworld Ethical clearance 2013_001).

Rating of the conservation importance of each reserve was based on the sum of the categorised scoring of the current IUCN-listed species (critically endangered $=4$; endangered $=$ 3 ; vulnerable $=2$; near threatened $=1$; least concern $=0$ ), level of endemism based on the proposed Maputaland-PondolandAlbany regional list of endemic to near-endemic species compiled by Perera et al (2011) $($ endemic $=2$; near endemic $=1)$, and the total number of species found per reserve.

Additional records were sourced from the Southern African Reptile Conservation Assessment (SARCA) (Bates et al. 2014), South African Frog Atlas Project (SAFAP) (Minter et al. 2004) and historical literature records pertaining to the study area (Appendix 3). Records with appropriate supporting evidence (identifiable photographs or voucher specimens) were 
included in the final species checklist, for example Burger (1996) and the Grobler photograph (see Figure 4c).

\section{Results and discussion}

A total of 22 amphibian species, representing 8 frog families and 15 genera (Table 1), and 37 reptile species (20 snakes, 16 lizards, 1 terrapin), representing 17 families and 33 genera (Table 2), were recorded from the six protected areas surveyed during this study (Appendix 2). This represents a near-complete list of species expected to occur along the Wild Coast (27 amphibian species were recorded by Minter et al. [2004] and 50 reptile species were recorded by Bates et al. [2014]). Although our survey excluded marine species, four species of marine turtle (Dermochelys coriacea, Chelonia mydas, Eretmochelys imbricata and Caretta caretta) and one sea snakes species (Hydrophis platurus) are expected to occur along the coastline (Bates et al. 2014). A total of three threatened amphibian and five threatened reptile species are represented in these protected areas. A total of 243 quarter-degree-unit (QDU) records were recorded, of which $37 \%$ (23\% amphibians and 50\% reptiles) represented first records for the respective units (Table 3), with southerly range extensions for 11 species. These include Arthroleptis wahlbergii, Breviceps cf. bagginsi, Hyperolius poweri, Leptopelis natalensis, Natalobatrachus bonebergi, Amblyodipsas concolor, Leptotyphlops sylvicolus, Psammophis brevirostris, Python natalensis, Thelotornis capensis capensis and Tropidosaura montana natalensis (see Tables 1, 2 and Appendix 1). The most southerly distribution in Africa was also recorded for the following genera: Amblyodipsas, Arthroleptis, Leptopelis, Natalobatrachus and Thelotornis (Appendix 1). Furthermore, the distribution of Bradypodion caffer was extended northwards. Range extensions exceeding $100 \mathrm{~km}$ were also recorded for A. concolor and P. brevirostris (Appendix 1). The distribution range of one species, T. montana natalensis, was extended to the Eastern Cape herpitofaunal list. A potential new species, which is related to Tetradactylus fitzsimonsi from the Port Elizabeth area, was discovered in Hluleka NR (Appendix 1). Hluleka, Silaka and Mkambati NRs had the greatest numbers of amphibian species, whereas Dwesa, Hluleka and Mkambati NRs had the greatest numbers of reptile species (Table 3 and Figure 2). With regard to amphibians, Silaka NR has a higher conservation importance, which can be attributed

TABLE 1: Amphibian checklist for six conservation areas surveyed along the Wild Coast, Eastern Cape, South Africa.

\begin{tabular}{|c|c|c|c|c|c|c|c|c|c|c|}
\hline \multirow[t]{3}{*}{ Species } & \multirow{3}{*}{$\begin{array}{l}\text { IUCN } \\
\text { status }\end{array}$} & \multicolumn{9}{|c|}{ Survey area and map reference } \\
\hline & & \multirow{2}{*}{$\frac{\text { Cape Morgan NR }}{3228 C B}$} & \multirow{2}{*}{$\frac{\text { Manubi SF }}{3228 \mathrm{BC}}$} & \multicolumn{2}{|c|}{ Dwesa NR } & \multirow{2}{*}{$\frac{\text { Hluleka NR }}{3129 C D}$} & \multicolumn{2}{|c|}{ Silaka NR } & \multicolumn{2}{|c|}{ Mkambati NR } \\
\hline & & & & 3228BD & 3228BB & & 3129CB & 3129DA & 3129BD & 3130AC \\
\hline \multicolumn{11}{|l|}{ Arthroleptidae } \\
\hline Arthroleptis wahlbergii Smith, 1849 & & & & & & $X^{b}$ & & $x$ & & \\
\hline Leptopelis natalensis Smith, 1849 & & & $X^{a, b}$ & $X^{a}$ & $x$ & $x$ & & $x$ & $x$ & $x$ \\
\hline \multicolumn{11}{|l|}{ Brevicipitidae } \\
\hline Breviceps cf. bagginsi Minter, 2003 & VU & & & & & & $X^{a, b}$ & $x$ & $x$ & \\
\hline Breviceps verrucosus Rapp, 1842 & & & & & & $x$ & & $x$ & $x$ & \\
\hline \multicolumn{11}{|l|}{ Bufonidae } \\
\hline Amietophrynus gutturalis Power, 1927 & & $x$ & $X^{a}$ & $x^{a}$ & & $x$ & $x$ & $x$ & $x$ & $x$ \\
\hline Amietophrynus rangeri Hewitt, 1935 & & $x$ & $x$ & $x^{a}$ & $x$ & $x$ & & & $x^{a}$ & $x^{a}$ \\
\hline \multicolumn{11}{|l|}{ Hyperoliidae } \\
\hline Afrixalus spinifrons Cope, 1862 & NT & & & & & $x$ & & $x$ & & \\
\hline $\begin{array}{l}\text { Hyperolius marmoratus verrucosus Smith, } \\
1849\end{array}$ & & $x$ & $x$ & $x$ & $x$ & $x$ & & $x$ & $x$ & $x$ \\
\hline Hyperolius poweri Loveridge, 1938 & & & & & & & & & $x^{b}$ & $x^{a}$ \\
\hline Hyperolius pusillus Cope, 1862 & & & $x^{a}$ & $x^{a}$ & & $x$ & & $x$ & & \\
\hline Hyperolius semidiscus Hewitt, 1927 & & $x$ & & $x^{a}$ & & $\mathrm{x}$ & & $x$ & & $x$ \\
\hline Kassina senegalensis Duméril \& Bibron, 1841 & & $x$ & $x$ & $x^{a}$ & & $\mathrm{x}$ & & $x$ & $x$ & $x^{a}$ \\
\hline \multicolumn{11}{|l|}{ Phrynobatrachidae } \\
\hline Phrynobatrachus natalensis Smith, 1849 & & $x$ & $x^{a}$ & $x^{a}$ & $x$ & $x$ & $x^{a}$ & $x$ & $x$ & $x$ \\
\hline \multicolumn{11}{|l|}{ Pipidae } \\
\hline Xenopus laevis Daudin, 1802 & & $x$ & $x$ & $x^{a}$ & $x$ & $\mathrm{x}$ & & $x$ & $x^{a}$ & $x$ \\
\hline \multicolumn{11}{|l|}{ Ptychadenidae } \\
\hline Ptychadena oxyrhynchus Smith, 1849 & & $\mathrm{x}$ & & $x^{a}$ & & $x$ & & $x$ & $x$ & $x$ \\
\hline Ptychadena porosissima Steindachner, 1867 & & & & & & & & & $x$ & $x$ \\
\hline \multicolumn{11}{|l|}{ Pyxicephalidae } \\
\hline Amietia quecketti Boulenger, 1895 "1894" & & $x$ & $x^{a}$ & $x$ & & $x$ & & $x$ & $x$ & $x$ \\
\hline Cacosternum nanum Boulenger, 1887 & & $\mathrm{x}$ & $x$ & $x^{a}$ & & $\mathrm{x}$ & & $\mathrm{x}$ & $\mathrm{x}$ & $\mathrm{x}$ \\
\hline Cacosternum boettgeri Boulenger, 1882 & & & & $\mathrm{x}$ & & & & & $\mathrm{x}$ & \\
\hline $\begin{array}{l}\text { Natalobatrachus bonebergi Hewitt \& } \\
\text { Methuen, } 1912\end{array}$ & EN & & $X^{a, b}$ & $x^{a}$ & $x$ & $x$ & $x^{a}$ & $x$ & & \\
\hline Strongylopus fasciatus Smith, 1849 & & $x$ & $x^{a}$ & $x$ & & $x$ & & $x$ & $x$ & $x$ \\
\hline Strongylopus grayii Smith, 1849 & & & & & & & & & $x$ & \\
\hline Tomopterna natalensis Smith, 1849 & & & & $x$ & & $x$ & & & $x$ & $x$ \\
\hline Total & 3 & 11 & 12 & 1 & & 18 & & 7 & 1 & \\
\hline
\end{tabular}

$\mathrm{EN}$, endangered; NR, nature reserve; NT, near threatened; SF, state forest; VU, vulnerable.

a, Denotes a new quarter-degree-unit record; ${ }^{b}$, denotes the southern-most distribution. 
TABLE 2: Reptile checklist for six conservation areas surveyed along the Wild Coast, Eastern Cape, South Africa.

\begin{tabular}{|c|c|c|c|c|c|c|c|c|c|c|c|}
\hline \multirow[t]{3}{*}{ Species } & \multirow[t]{3}{*}{ IUCN status } & \multicolumn{10}{|c|}{ Survey area and map reference } \\
\hline & & \multirow{2}{*}{$\frac{\text { Cape Morgan NR }}{3228 C B}$} & \multirow{2}{*}{$\begin{array}{c}\text { Manubi SF } \\
3228 \mathrm{BC} \\
\end{array}$} & \multicolumn{2}{|c|}{ Dwesa NR } & \multirow{2}{*}{$\frac{\text { Hluleka NR }}{3129 C D}$} & \multicolumn{2}{|c|}{ Silaka NR } & \multicolumn{3}{|c|}{ Mkambati NR } \\
\hline & & & & 3228 BD & 3129BD & & 3129CB & 3129DA & 3129BD & $3130 A C$ & 3130AA \\
\hline \multicolumn{12}{|l|}{ Pelomedusidae } \\
\hline $\begin{array}{l}\text { Pelomedusa galeata Schoepff, } \\
1972\end{array}$ & & & $x^{a}$ & $x^{a}$ & & $x^{a}$ & & $x^{a}$ & & $x^{a}$ & \\
\hline \multicolumn{12}{|l|}{ Crocodylidae } \\
\hline $\begin{array}{l}\text { Crocodylus niloticus Laurenti, } \\
1768\end{array}$ & VU & & & $\mathrm{x}$ & & & & & & & \\
\hline \multicolumn{12}{|l|}{ Gekkonidae } \\
\hline $\begin{array}{l}\text { Afroedura pondolia Hewitt, } \\
1925\end{array}$ & & & & $x^{b}$ & $x$ & $\mathrm{x}$ & & $x$ & $x^{a}$ & & $\mathrm{x}$ \\
\hline $\begin{array}{l}\text { Hemidactylus mabouia Moreau } \\
\text { de Jonnès, } 1818\end{array}$ & & $x$ & $x$ & $x^{a}$ & & $x$ & & $x$ & $x$ & $x^{a}$ & \\
\hline $\begin{array}{l}\text { Lygodactylus capensis Smith, } \\
1848\end{array}$ & & $x$ & $x$ & & & & & $x$ & & & \\
\hline $\begin{array}{l}\text { Pachydactylus maculatus Gray, } \\
1845\end{array}$ & & $x$ & $x$ & & & & & & & & \\
\hline
\end{tabular}

\section{Lacertidae}

Tropidosaura montana

natalensis FitzSimons, 1947

\section{Cordylidae}

Chamaesaura anguina

Linnaeus, 1758

\section{Gerrhosauridae}

Gerrhosaurus flavigularis

Wiegmann, 1828

Tetradactylus cf. fitzsimonsi

Hewitt, 1915

\section{Scincidae}

Acontias plumbeus Bianconii,

1849

Trachylepis homalocephala

Wiegmann, 1828

Trachylepis varia Peters, 1867

\section{Varanidae}

Varanus niloticus Linnaeus,

1758

Chamaeleonidae

Bradypodion caffer Boettger,

1889

Bradypodion ketanicum Hewitt, VU

1935

\section{Agamidae}

Agama atra Daudin, 1802

Typhlopidae

Afrotyphlops bibronii Smith,

1846

Leptotyphlopidae

Leptotyphlops sylvicolus

Broadley \& Wallach, 1997

\section{Pythonidae}

Python natalensis Smith, 1840

$\mathrm{X}^{\mathrm{a}}$

\section{Viperidae}

Bitis arietans Merrem, 1820

Causus rhombeatus

Lichtenstein, 1823

Lamprophiidae

Amblyodipsas concolor Smith

1849

Boaedon capensis Dumeril

1854

Duberria lutrix lutrix Lunnaeus,

1758

Lycodonomorphus inornatus

Duméril \& Bibron, 1854

Lycodonomorphus rufulus

Lichtenstein, 1823

Lycophidion capense Smith,

$x^{a} \quad x^{a} \quad x^{a} \quad x^{a} \quad x^{a}$

$X^{a}-x^{2}$

$X^{\mathrm{a}} \quad \mathrm{X}^{\mathrm{a}} \quad \mathrm{X}-\mathrm{X}^{\mathrm{a}}$

$x \quad x$

$x$

$X^{a}$

$\begin{array}{llll}X^{a} & x & x & X^{a}\end{array}$

$x-x^{a}-x-x^{a}-x$

$\mathrm{X} \quad \mathrm{X}^{\mathrm{a}, \mathrm{c}}$

V X $\quad x \quad x$

X

$x \quad x \quad x$

X $\quad x-x-x-x$

$\mathrm{X}^{\mathrm{a}, \mathrm{b}}$

$X^{a, b}$

$x \quad x \quad x^{a} \quad x \quad \begin{array}{lll}x & x^{a}\end{array}$

$\begin{array}{cc}x^{a, b} & x^{a} \\ x^{a} & x^{a} \\ x^{a} & x^{a} \\ & \end{array}$

$x^{a}$

$x \quad x^{a}$ 
TABLE 2 (continues...): Reptile checklist for six conservation areas surveyed along the Wild Coast, Eastern Cape, South Africa.

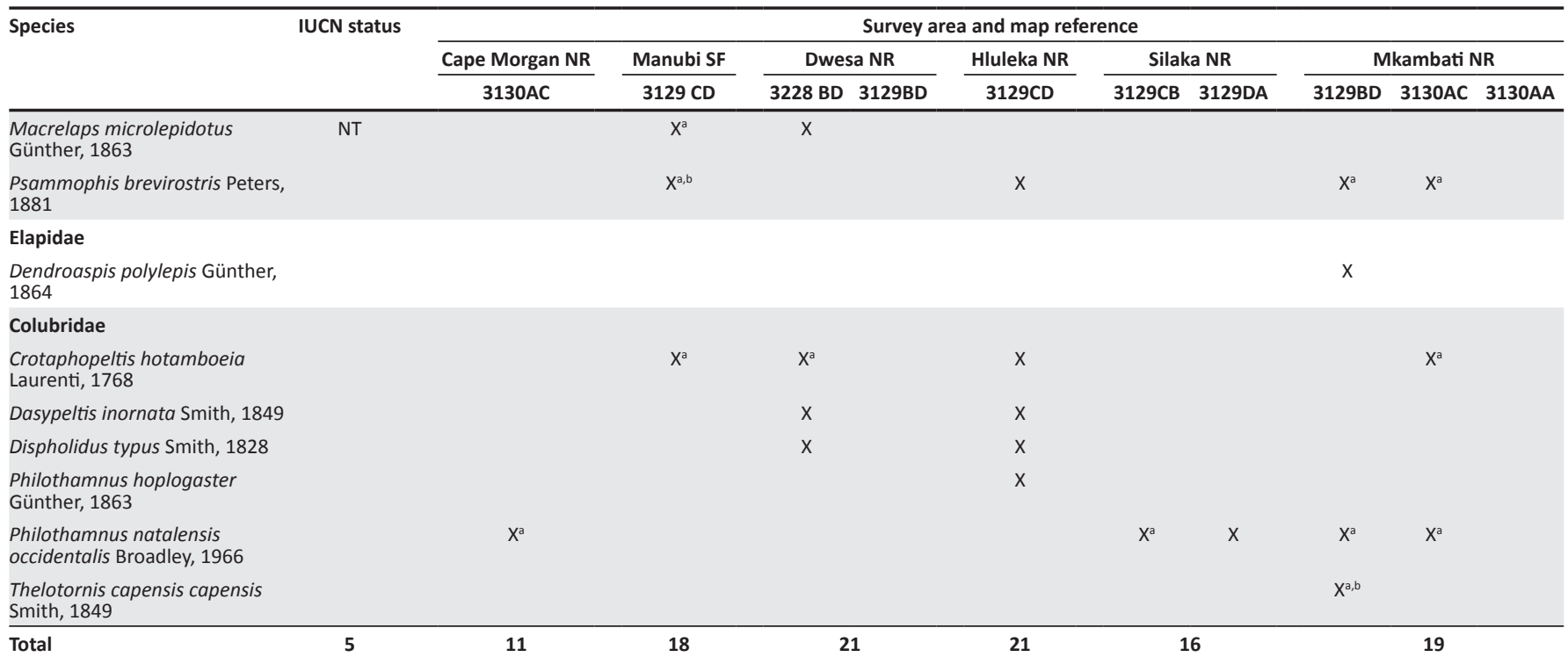

EN, endangered; NR, nature reserve; NT, near threatened; SF, state forest; VU, vulnerable. a Denotes a new quarter-degree-unit record.

$b$, Denotes the southern-most distribution; ' , denotes the northern-most distribution.

TABLE 3: New quarter-degree-unit records for South Africa and conservation importance score of six conservation areas studied along the Wild Coast, Eastern Cape, South Africa.

\begin{tabular}{|c|c|c|c|c|c|c|}
\hline \multirow[t]{2}{*}{ Records } & \multicolumn{6}{|c|}{ Conservation area } \\
\hline & Cape Morgan NR & Manubi SF & Dwesa NR & Hluleka NR & Silaka NR & Mkambati NR \\
\hline \multicolumn{7}{|l|}{ Reptiles } \\
\hline Number of reptile species & 11 & 18 & 21 & 21 & 16 & 19 \\
\hline Number of QDU records & 11 & 18 & 26 & 21 & 20 & 30 \\
\hline Number of new QDU records & 6 & 11 & 11 & 9 & 6 & 20 \\
\hline Percentage new QDU records (\%) & 55 & 61 & 42 & 43 & 30 & 67 \\
\hline Reptile conservation importance score & 11 & 26 & 34 & 34 & 22 & 28 \\
\hline \multicolumn{7}{|l|}{ Amphibians } \\
\hline Number of amphibian species & 11 & 12 & 16 & 18 & 17 & 19 \\
\hline Number of QDU records & 11 & 12 & 22 & 18 & 21 & 33 \\
\hline Number of new QDU records & 0 & 7 & 11 & 1 & 3 & 5 \\
\hline Percentage new QDU records (\%) & 0 & 58 & 50 & 6 & 14 & 15 \\
\hline Amphibian conservation importance score & 13 & 20 & 25 & 33 & 37 & 31 \\
\hline Overall conservation importance score & 24 & 46 & 59 & 67 & 59 & 56 \\
\hline
\end{tabular}

NR, nature reserve; QDU, quarter-degree unit; SF, state forest.

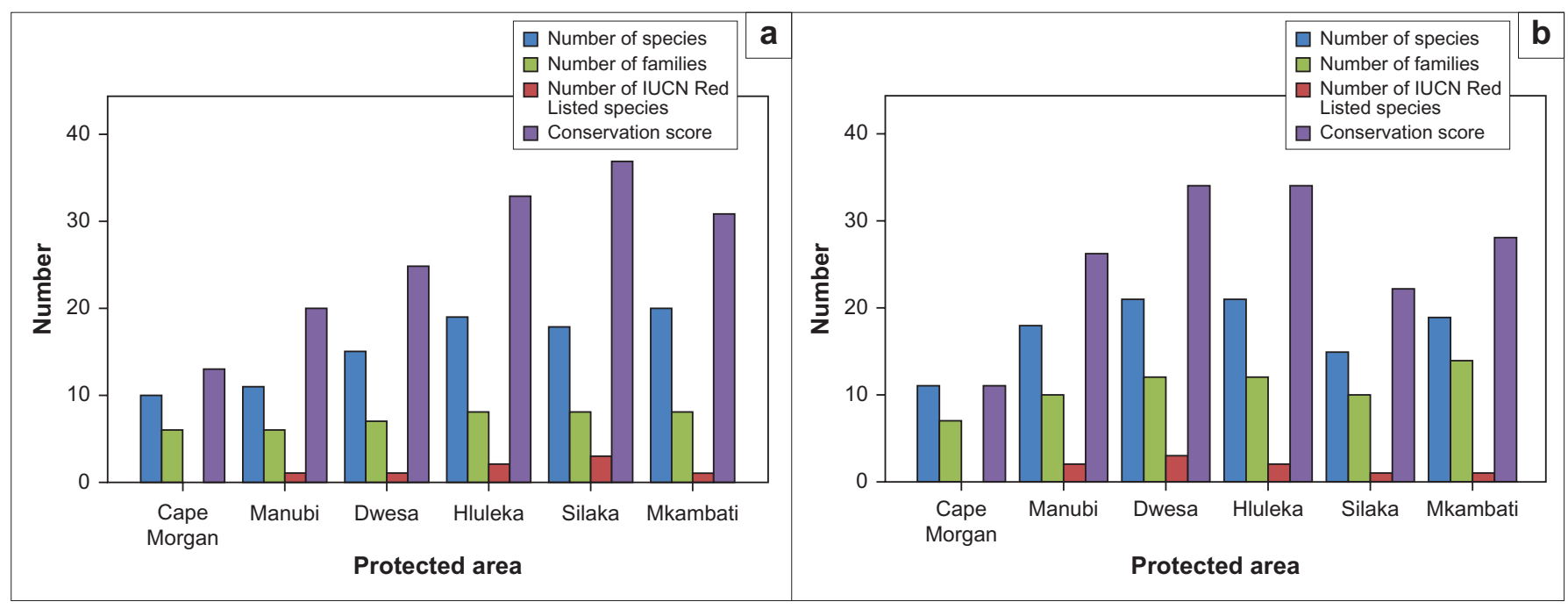

Source: Jan A. Venter

FIGURE 2: A comparison of the number of (a) amphibian and (b) reptile species and families and number of IUCN Red Listed species, as well as the conservation importance scores recorded in the six protected areas during the study. 

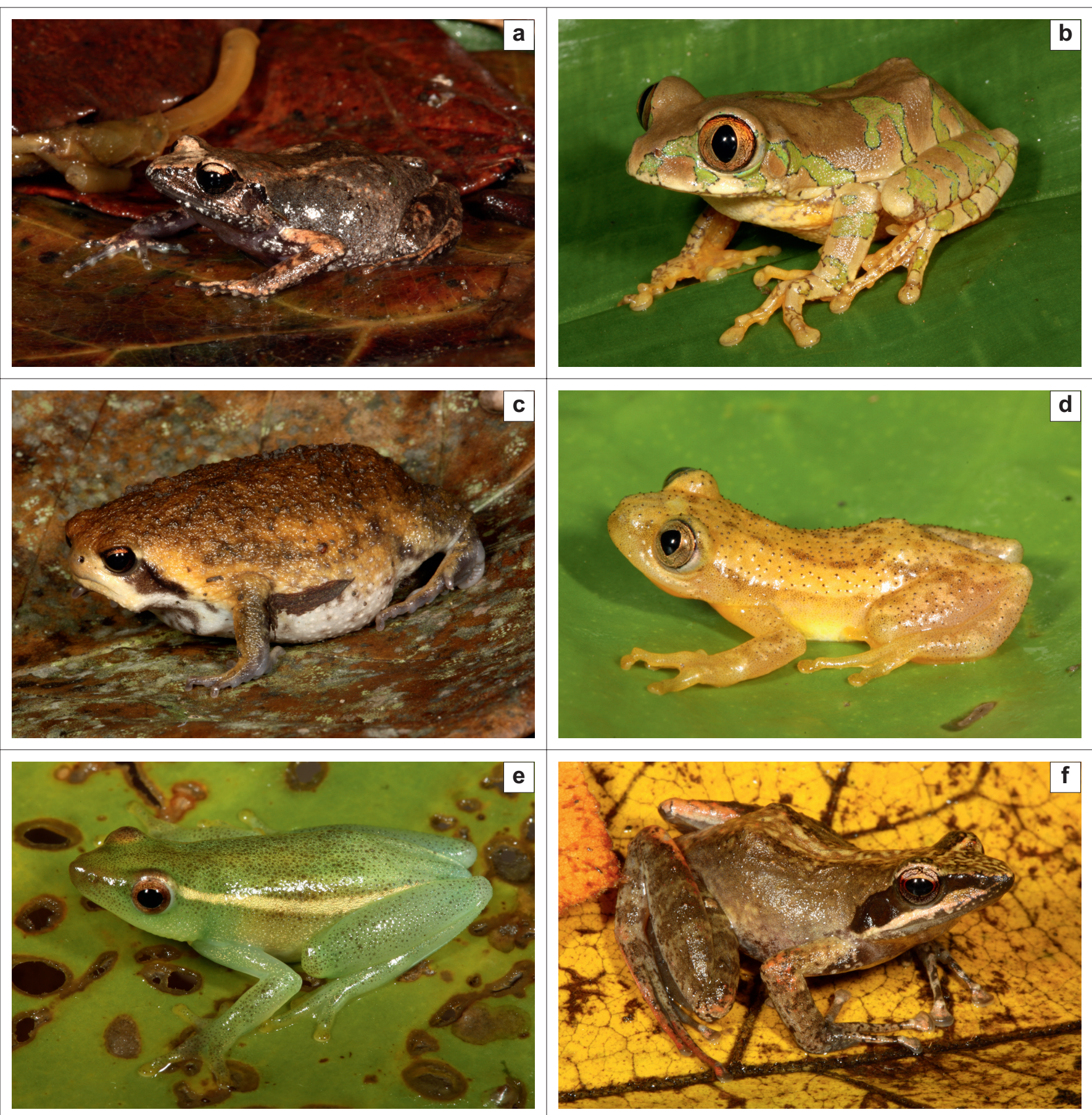

Source: Werner Conradie

FIGURE 3: Amphibian species of special or conservation concern recorded in protected areas along the Wild Coast, including (a) Arthroleptis wahlbergii (Hluleka NR), (b) Leptopelis natalensis (Silaka NR), (c) Breviceps cf. bagginsi (Silaka NR), (d) Afrixalus spinifrons (Hluleka NR), (e) Hyperolius poweri (Mkambati NR) and (f) Natalobatrachus bonebergi (Manubi SF).

to the presence of three threatened, five endemic and three near-endemic species. Both Dwesa and Hluleka NRs are important for reptile conservation, as they are home to at least two threatened, three endemic and two near-endemic species each. Regarding overall conservation importance, Hluleka NR scored the highest, followed by, in descending order, Dwesa NR, Mkambati NR, Silaka NR, Manubi SF and Cape Morgan NR (Table 3 and Figure 2). Species of special conservation concern or noteworthy records are illustrated in Figures 3 and 4.

\section{Conclusion}

We provide valuable data on amphibian and reptilian species presence and distribution for a fairly under-sampled region in South Africa. Our study further highlights the importance of baseline survey work to inform conservation management planning for protected areas and species of special conservation concern. The discovery of several healthy and thriving populations of threatened species, such as B. cf. bagginsi, N. bonebergi, Afrixalus spinifrons, Macrelaps 

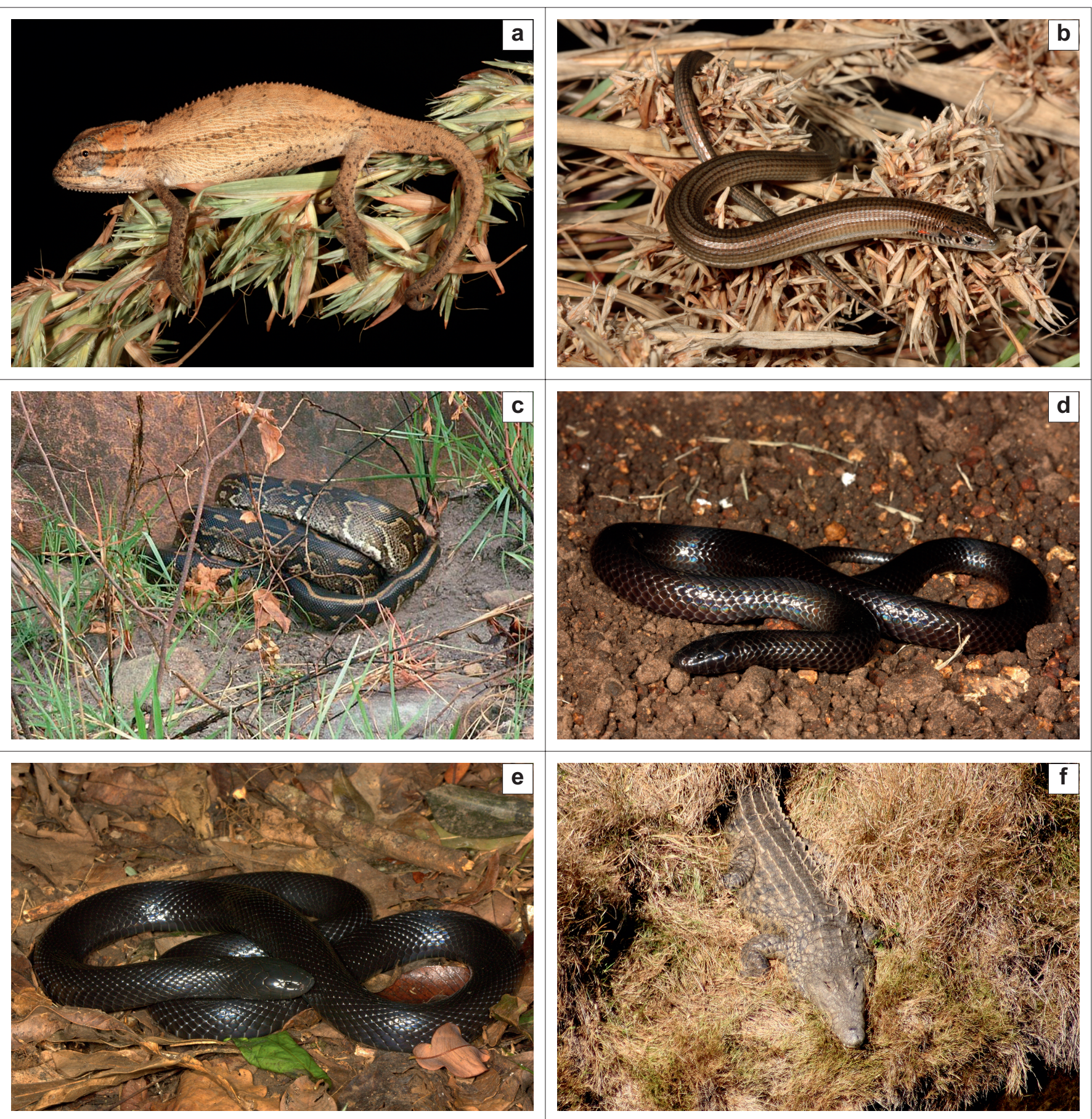

Source: Werner Conradie (a, b, d, e); Quartus Grobler (c); Jan A. Venter (f).

FIGURE 4: Reptile species of special or conservation concern recorded in protected areas along the Wild Coast, including (a) Bradypodion caffer (Mkambati NR), (b) Tetradactylus cf. fitzsimonsi (Hluleka NR), (c) Python natalensis (Mkambati NR), (d) Amblyodipsas concolor (Hluleka NR), (e) Macrelaps microlepidotus (Manubi SF) and (f) Crocodylus niloticus (Dwesa NR).

microlepidotus and Bradypodion spp., is very encouraging. It further indicates that even small protected areas, as is the case with Silaka NR, Hluleka NR and Manubi SF, play an important role in conserving a number of threatened species, considering the development pressure many of these species face in KwaZulu-Natal (Minter et al. 2004). Future research should focus on investigating the impact of current land-use activities (communal subsistence farming) on species conservation along the Wild Coast compared with that of commercial agriculture, forestry and high-density development in areas such as south-western KwaZulu-Natal. This is especially important because of the significant and increasing pressure placed on the Wild Coast region owing to slash-and-burn agriculture, illegal activities such as sand mining, road construction and logging, as well as water pollution from neglected or non-functional municipal sewage treatment works (De Villiers \& Costello 2013). Significant portions of land 
north-east of Mkambati NR (Xolobeni area) are currently being considered for mining, which, together with the construction of the proposed national (N2) toll road, will result in additional habitat loss and fragmentation for several important herpetofaunal species. It is therefore critical that the current protected areas in the region remain secure and that opportunities are sought to increase the size of the protected areas in the region to form corridors for dispersal. In addition, it is crucial that local, provincial and national government agencies take note of the potential negative consequences of increased land degradation in the region, the effect on biodiversity and the subsequent impact on local communities.

Our study provides the first checklist for amphibians and reptiles from the Wild Coast protected areas, but gaps remain owing to factors related to spatial and temporal under-sampling. The results reported here represent only one sampling trip per protected area, conducted during either early or late summer, which may have led to species being missed owing to non-breeding or inactivity. It is important that further surveys and monitoring are conducted to increase sampling effort and to capture seasonal differences in species assemblages and densities. Monitoring at regular intervals, in order to measure the effect of land use or climate change on the populations of threatened species especially, is recommended. Our surveys focused on the coastal areas of the Wild Coast, with the inland area of the Transkei remaining under-sampled. A rich source of undiscovered herpetofaunal diversity is likely to still be uncovered.

\section{Acknowledgements}

The Eastern Cape Parks and Tourism Agency (ECPTA) funded the study. Neil Brown and numerous students from the Parks and People program of Penn State University provided valuable field assistance. Juan Greeff (ECPTA) provided technical assistance. Gillian Watson (Port Elizabeth Museum, Bayworld) allowed the examination of specimens in her care. Lemmy Mashini (Ditsong National Museum of Natural History) provided data of TM specimens. Andrew Turner (CapeNature) provided additional records. René Navarro (Avian Demography Unit, University of Cape Town) provided SAFAP and SARCA data. Krystal Tolley (South African National Biodiversity Institute), Savel Daniels (Stellenbosch University), Div de Villiers (Eastern Cape Department of Economic Development and Environmental Affairs) and Marius Burger provided valuable inputs on certain species account sections. Christa Conradie provided proofreading services.

\section{Competing interests}

The authors declare that they have no financial or personal relationships that may have inappropriately influenced them in writing this article.

\section{Authors' contributions}

J.A.V. (Nelson Mandela Metropolitan University) was the project leader. He was responsible for experimental design, conducted fieldwork and performed data analysis. W.C. (Port Elizabeth Museum) assisted in experimental design, conducted fieldwork, handled all preservation and lodging of specimens and performed data analysis.

\section{References}

Bates, M.F., Branch, W.R., Bauer, A.M., Burger, M., Marais, J., Alexander, G.J. et al., 2014, Atlas and red list of the reptiles of South Africa, Lesotho and Swaziland, South African National Biodiversity Institute, Pretoria (Suricata series; no. 1)

Böhm, M., Collen, B., Baillie, J.E.M., Bowles, P., Chanson, J., Cox, N. et al., 2013, 'The conservation status of the world's reptiles', Biological Conservation 157, 372-385. http://dx.doi.org/10.1016/j.biocon.2012.07.015

Botts, E., Erasmus, B.N. \& Alexander, G., 2011, 'Geographic sampling bias in the South African Frog Atlas Project: Implications for conservation planning', Biodiversity and Conservation 20(1), 119-139. http://dx.doi.org/10.1007/ s10531-010-9950-6

Branch, W.R., 1998, Field guide to the snakes and other reptiles of southern Africa, Struik, Cape Town.

Branch, W.R., 2006, 'Priorities for systematic studies on southern African reptiles', in W.R. Branch, K.A. Tolley, M. Cunningham, A.M. Bauer, G. Alexander, J.A Harrison et al. (eds.), A plan for phylogenetic studies of southern African reptiles: Proceedings of a workshop held at Kirstenbosch, February 2006, pp. 1-15, South African National Biodiversity Institute, Pretoria (SANBI Biodiversity Series; no 5).

Branch, W.R., 2014, 'Conservation status, diversity, endemisim, hotspots and threats', in M.F. Bates, W.R. Branch, A.M. Bauer, M. Burger, J. Marais, G.J. Alexander et al. (eds.), Atlas and red data list of the reptiles of South Africa, Lesotho and Swaziland pp. 22-50, South African National Biodiversity Institute, Pretoria (Suricata series; pp. $22-50$,
no. 1).

Branch, W.R., Benn, G.A. \& Lombard, A.T., 1995, 'The tortoises (Testudinidae) and terrapins (Pelomedusidae) of southern Africa: Their diversity, distribution and conservation', South African Journal of Zoology 30, 91-102.

Branch, W.R. \& Haagner, G.V., 1999, 'Geographical distribution: Psammophis brevirostris and Acontias sp.: The value of road kills', African Herp News 30, 37-38.

Burger, M., 1996, 'Report on a herp[e]tofaunal survey conducted in the former Transkei region', unpublished report, Ministry of Economic Affairs, Environment \& Tourism, Eastern Cape Nature Conservation.

Channing, A., 2001, Amphibians of central and southern Africa, Cornell University Press, New York.

Channing, A. \& Baptista, N., 2013, 'Amietia angolensis and A. fuscigula (Anura: Pyxicephalidae) in southern Africa: A cold case reheated', Zootaxa 3640, 501-520. http://dx.doi.org/10.11646/zootaxa.3640.4.1

Channing, A., Hillers, A., Lotters, M.O., Schick, S., Conradie, W., Rodder, D. et al., 2013, 'Taxonomy of the super-cryptic Hyperolius nasutus group of long reed frogs of 'Taxica (Anura: Hyperoliidae), with descriptions of six new species', Zootaxa 3620 Africa (Anura: Hyperoliidae), with descriptions of six new
301-350. http://dx.doi.org/10.11646/zootaxa.3620.3.1

Conroy, C.J., Papenfuss, T., Parker, J. \& Hahn, N.E., 2009, 'Use of tricaine methanesulfonate (MS222) for euthanasia of reptiles', Journal of the American Association for Laboratory Animal Science 48, 28-32.

De Villiers, D. \& Costello, J., 2013, Mkambati and the Wild Coast, 2nd edn., Div de Villiers and John Costello, Port St Johns.

Dippenaar, A.S., Hamer, M. \& Haddad, C.R., 2011, 'Spiders (Arachnida: Araneae) of the vegetation layer of the Mkambati Nature Reserve, Eastern Cape, South Africa', Koedoe 53(1), 1-10.

Du Preez, L.H. \& Curruthers, V.C., 2009, A complete guide to the frogs of southern Africa, Struik Nature, Cape Town.

FitzSimons, V.F.M., 1930, 'Descriptions of new South African Reptilia and Batrachia, with distribution records of allied species in the Transvaal Museum collection', Annals of the Transvaal Museum 14, 20-48.

Frost, D.R., 2014, Amphibian species of the world: An online reference, Version 6.0, online database, viewed 24 June 2014, from http://research.amnh.org/ herpetology/amphibia/index.html, American Museum of Natural History, New York.

Haagner, G.V., 1994, 'Geographical distribution: Amblyodipsas concolor', African Herp News 21, 26.

Hoare, D.B., Mucina, L., Rutherford, M.C., Vlok, J., Euston-Brown, D.I.W., Palmer, A.R. et al., 2006, 'Albany thicket biome', in L. Mucina \& M.C. Rutherford (eds.) The vegetation of South Africa, Lesotho and Swaziland, South African National Biodiversity Institute, Pretoria.

Marais, J., 2004, A complete guide to the snakes of southern Africa, Struik, Cape Town.

Measey, G.J., 2011, Ensuring a future for South Africa's frogs: A strategy for conservation research, South African National Biodiversity Institute, Petoria (SANBI Biodiversity Series; no. 19).

Measey, G.J., Armstrong, A.J. \& Hanekom, C., 2009, 'Subterranean herpetofauna show a decline after 34 years in Ndumu Game Reserve, South Africa', Oryx 43(2), 284 287. http://dx.doi.org/10.1017/S0030605307002311 
Minter, L.R., Burger, M., Harrison, J.A., Braack, H.H., Bishop, P.J. \& Kloepfer, D., 2004 Atlas and red data book of the frogs of South Africa, Lesotho and Swaziland, Smithsonian Institute, Cape Town.

Mittermeier, R.A., Robles-Gil, P., Hoffman, M., Pilgrim, J.D., Brooks, T., Mittermeier, C. et al., 2004, Revisited: Earth's biologically richest and most endangered ecoregions, CEMEX, Mexico City.

Mokhatla, M.M., Measey, G.J., Chimimba, C.T. \& Van Rensburg, B.J., 2012, 'A biogeographical assessment of anthropogenic threats to areas where different frog breeding groups occur in South Africa: Implications for anuran conservation', Diversity and Distributions 18(5), 470-480. http://dx.doi.org/10.1111/j.1472 4642.2011.00870.x

Mucina, L. \& Geldenhuys, C.J., 2006, 'Afrotemperate, subtropical and azonal forests', in L. Mucina \& M.C. Rutherford (eds.), The vegetation of South Africa, Lesotho and Swaziland, pp. 584-614, South African National Biodiversity Institute, Pretoria.

Mucina, L., Scott-Shaw, C.R., Rutherford, M.C., Camp, K.G.T., Matthews, W.S., Powrie, L.W. et al., 2006, 'Indian Ocean coastal belt', in L. Mucina \& M.C. Rutherford (eds.), The vegetation of South Africa, Lesotho and Swaziland, pp. 568-583, South African National Biodiversity Institute, Pretoria.

Ochoa-Ochoa, L., Urbina-Cardona, J.N., Vázquez, L.-B., Flores-Villela, O. \& Bezaury Creel, J., 2009, 'The effects of governmental protected areas and social initiative for land protection on the conservation of Mexican amphibians', PLOS ONE 4(9), e6878, 9 pages.

Perera, S.J., Ratnayake-Perera, D. \& Proches, S., 2011, 'Vertebrate distributions indicate a greater Maputaland-Pondoland-Albany region of endemism', South African Journal of Science 107(7/8), 1-15. http://dx.doi.org/10.4102/sajs.v107i7/8.462

Petzold, A., Vargas-Ramirez, M., Kehlmaier, C., Vamberger, M., Branch, W.R., Du Preez, L. et al., 2014, 'A revision of African helmeted terrapins (Testudines: Pelomedusidae: Pelomedusa), with descriptions of six new species', Zootaxa 3795, 523-548. http://dx.doi.org/10.11646/zootaxa.3795.5.2

Power, J.H., 1935, 'Contribution to the herpetology of Pondoland', Proceedings of the Zoological Society of London 1935, 333-346. http://dx.doi.org/10.1111/ j.1469-7998.1935.tb06253.x
Russell, K.R., Lear, D.H.V. \& Guynn Jr, D.C., 1999, 'Prescribed fire effects on herpetofauna: Review and management implications', Wildlife Society Bulletin 27(2), 374-384.

Skead, C.J., 2007, Historical incidence of the larger mammals in the broader Eastern Cape, 2nd edn., Nelson Mandela Metropolitan University, Port Elizabeth.

Tuberville, T.D., Willson, J.D., Dorcas, M.E. \& Gibbons, J.W., 2005, 'Herpetofauna species richness of southeastern national parks', Southeastern Naturalist 4(3) 537-569. http://dx.doi.org/10.1656/1528-7092(2005)004[0537:HSROSN]2.0.CO;2

Uetz, P., 2014, The reptile database, viewed 23 June 2014, from http://www.reptiledatabase.org/

Van Wyk, A.E. \& Smith, G.F., 2001, Regions of floristic endemism in Southern Africa, Umdaus Press, Hatfield.

Venter, J.A. \& Conradie, W., 2011, 'The herpetological fauna of Mkambati Nature Reserve: A report on the herp[e]tological survey conducted in February 2011', unpublished report, Eastern Cape Parks and Tourism Agency, East London.

Venter, J.A. \& Conradie, W., 2012a, 'The amphibians and reptiles of Cape Morgan and Double-Mouth Nature Reserves', unpublished report, Eastern Cape Parks and Tourism Agency, East London.

Venter, J.A. \& Conradie, W., 2012b, 'The amphibians and reptiles of Dwesa Nature Reserve: A report on a rapid biodiversity survey conducted in February 2012', unpublished report, Eastern Cape Parks and Tourism Agency, East London.

Venter, J.A. \& Conradie, W., 2012c, 'The amphibians and reptiles of Hluleka Nature Reserve: A report on a rapid biodiversity survey conducted in October 2011', unpublished report, Eastern Cape Parks and Tourism Agency, East London.

Venter, J.A., Conradie, W. \& Greeff, J., 2012, 'The amphibians and reptiles of Silaka Nature Reserve: A report on a rapid biodiversity survey conducted in October 2012', unpublished report, Eastern Cape Parks and Tourism Agency, East London.

Venter, J.A., Conradie, W., Pfeiffer, M. \& Greeff, J., 2013, 'The reptiles, frogs, birds, mammals and dragonflies of Manubi Forest and expansion areas', unpublished report, Eastern Cape Parks and Tourism Agency, East London.

Venter, J.A., Prins, H.H.T., Balfour, D.A. \& Slotow, R., 2014, 'Reconstructing grazer assemblages for protected area restoration', PLOS ONE 9(3), e90900, 10. 


\section{Appendix 1}

\section{Species accounts}

This section provides selective species accounts (excluding common and widespread species, marine turtles and sea snakes) to highlight special records for the region. Species account information was sourced from the individual species account sections in Minter et al. (2004) and Bates et al. (2014), and updated with our new records unless stated otherwise. Families are organised according to Frost (2014) for Amphibia and Bates et al. (2014) for Reptilia. Species of special conservation concern or noteworthy records are illustrated in Figures 3 and 4 in the main text. All additional PEM holdings collected and used in this study are listed in Appendix 2 and additional records derived from other sources are listed in Appendix 3. Records labelled as PEM A refer to amphibian records from the Port Elizabeth Museum, those labelled PEM T refer to tadpole records from this collection and those labelled PEM R refer to reptilian records from the collection.

\section{Amphibia}

\section{ARTHROLEPTIDAE}

\section{Arthroleptis wahlbergii Smith, 1849 (Bush squeaker)}

This species is endemic to the coastal forest patches of the east coast of South Africa, from the border of Mozambique to just south of Port St Johns. Because of this restriction, the species is under encroachment pressure owing to agricultural and urban development. The Hluleka NR (3129CD) specimens represent the most southern distribution of the species, as well as for the genus in Africa. Two additional inland records from Mqanduli (PEM A7368, PEM A7369) are included in the PEM collection. FitzSimons (1930) considered the population around Port St Johns as a new species, namely Arthroleptis wageri, citing a broader head, shorter hind limbs and larger general size. This arrangement was also followed by Laurent (1941). However, Poynton (1964) synonymised this species with the more common $A$. wahlbergii. Genetic studies currently underway on this species show substantial genetic differentiation for this Eastern Cape population, pointing to the possibility that $A$. wageri might be a valid species (K. Tolley pers. comm., 14 July 2014). The species was recorded only from Hluleka and Silaka NRs during this study.

\section{BREVICIPITIDAE}

Breviceps cf. bagginsi Minter, 2003 (Bilbo's rain frog)

A series of specimens collected from Silaka NR (3129CB,-DA) during this study and one additional PEM specimen (PEM A11122) previously collected $15 \mathrm{~km}$ west of Mkambati NR (3129BB, new QDU record) have temporarily been assigned to Breviceps bagginsi, based on the call and morphology. In Silaka NR, specimens were captured in traps associated with grassland habitat (see 'Study area'). These new records potentially expand the known distribution of this species southwards to the Port St Johns area. Burger (1996) reported an unidentified Breviceps species from Mkambati NR (3129BD), recorded as Breviceps mossambicus by Minter (2004b) and later identified as B. bagginsi (Measey 2011). The specific specimen is not available in any museum collection and thus could not be verified. This species belongs to the B. mossambicus complex and further studies are needed in the northern coastal Eastern Cape to determine whether the applicable records of B. mossambicus in Minter (2004b) can be assigned to B. bagginsi. Minter (2004b) mistakenly reported B. mossambicus as occurring as far south as Mkambati NR, but the provided QDU actually represents Port St Johns. $B$. bagginsi is a recently described species known only from four KwaZulu-Natal QDU records (Minter 2004a) and is believed to be endemic to KwaZulu-Natal. Thus, the new distribution records for the Eastern Cape and the presence in a protected area will contribute to protecting the species. The species is currently rated as vulnerable (Measey 2011). The species was recorded only from Silaka NR during this study.

\section{HYPEROLIIDAE}

Afrixalus spinifrons Cope, 1862 (Natal leaf-folding frog)

An endemic South African species distributed from St. Lucia Village in the north to Cintsa Bay and Kei Road in the south. Pickersgill (1996) assigned the Eastern Cape populations to A. spinifrons spinifrons, but Tarrant (2012) showed that, according to molecular description, Eastern Cape populations should be referred to Afrixalus spinifrons intermedius. The species is currently rated as near threatened (Measey 2011). Whilst documenting and photographing freshly laid eggs in situ at Silaka NR, an adult ran up the stem of the leaf to the clutch and assumed a threatening posture. This behaviour can possibly be attributed to a form of parental care or protection, which has never been reported for the species. The species was found in both Silaka and Hluleka NRs during the study.

\section{Hyperolius poweri Loveridge, 1938}

Channing et al. (2013a) assigned the KwaZulu-Natal and Eastern Cape populations of the Hyperolius nasutus complex (for which Mkambati NR is the most southern distribution) to $H$. poweri based on genetics and calls. Because of the recent taxonomical change, the species' threatened status has not been assessed. However, owing to its patchy distribution along the east coast of South Africa and loss of habitat due to agricultural and urban development, the species may in the future be considered threatened and treated as a separate conservation unit. The species was found in Mkambati NR during the study, which is the only known occurrence of the species in the Eastern Cape.

\section{PYXICEPHALIDAE}

\section{Cacosternum boettgeri Boulenger, 1882 (Boettger's caco)}

Recent revision of the genus by Channing et al. (2013b) indicated the presence of cryptic diversity and led to the description of four new species (Cacosternum aggestum, Cacosternum australis, Cacosternum nanogularum and Cacosternum rhythmum), with Conradie (2014) describing another species within the C. boettgeri complex (Cacosternum thorini). In both studies, no material from coastal Eastern Cape or KwaZulu-Natal was used. Populations from these areas may hold further cryptic diversity. Burger (1996) 
reported this species to be present in Mkambati NR based on the call only, and the SAFAP database lists a voucher specimen collected from Dwesa NR in late 1991. The specimen is unaccounted for in any of the South African museums; thus, its identification cannot be verified. Owing to its possible distribution, we tentatively include this species in our records. However, no new material has been collected from any of the reserves surveyed during the current study. Further surveys in optimal conditions are needed to confirm the presence of this species from coastal Eastern Cape.

\section{Natalobatrachus bonebergi Hewitt \& Methuen, 1912 (Kloof frog)}

The species is currently known from only nine localities in KwaZulu-Natal and the Eastern Cape (Measey 2011). Historically, it has been recorded from 18 QDUs (Du Preez 2004), of which three are in the Eastern Cape. During the frog atlas period (1996-2002), only two of the historical sites were confirmed and one new QDU was added (Dwesa NR, 3228BB), which represented its most southern distribution (Du Preez 2004). We report three new QDU records (3228BD, 3129CB and 3228BC), which now represent the most southern distribution, and confirm the two historical QDU sites (3129DA and 3129CD) previously recorded. This increases the existing distribution to seven QDU sites within the Eastern Cape, including 3228BB and the historical record (3229CC). The habitat of $N$. bonebergi is currently being heavily affected by agricultural clearing (especially for sugar cane) and urbanisation, particularly in KwaZuluNatal (Measey 2011). As a result, populations of this species are becoming severely fragmented and are thus regarded as endangered (Measey 2011).

\section{Reptilia}

\section{CROCODYLIDAE}

\section{Crocodylus niloticus Laurenti, 1768 (Nile crocodile)}

Crocodiles are restricted to the northern and eastern parts of South Africa. They were re-introduced to Dwesa NR in 1979 (Pooley 1980), which has been criticised as 'ill-advised' by Marais (2014a). This criticism may be unwarranted because good evidence exists that the species historically (during the 19th and early 20th centuries) occurred even further south than the current location in Dwesa NR, with the last record of a crocodile killed in the former Transkei recorded in the Mendwana river, Dwesa Forest in 1903 (Feely 2010). Evidence also exists that the re-introduced Dwesa NR population did successfully breed (Feely 2010; Venter \& Conradie 2012), but the survival rate of young crocodiles is still to be determined. Only two adults were recorded in the latest game census (Peinke \& Gibisela 2013). This species is rated as vulnerable (Bates et al. 2014).

\section{GEKKONIDAE}

\section{Afroedura pondolia Hewitt, 1925 (Pondo flat gecko)}

This species is endemic to the Eastern Cape and KwaZuluNatal coast and associated with scattered inland records. It reaches its southern distribution limit around the coastal
Dwesa NR (3228BD) and inland Butterworth (3228AD) area. It is present in Mkambati, Silaka (TM 76520), Hluleka and Dwesa NRs.

Lygodactylus capensis Smith, 1848 (Common dwarf gecko) This is a common and widespread diurnal gecko species, which is not native to the Eastern Cape (Branch 2014). Populations at Silaka and Cape Morgan NRs were most likely accidentally introduced by tourists visiting the reserves. All specimens collected or observed were limited to buildings and other human-made structures.

\section{LACERTIDAE}

Tropidosaura montana natalensis FitzSimons, 1947 (Common mountain lizard)

This subspecies is restricted to southern KwaZulu-Natal, where it is found in both coastal and montane grassland. A single record from Mkambati NR was recorded during this study, its remains being regurgitated by a Lycophidion capense. This is the first record for this species in the Eastern Cape.

\section{GERRHOSAURIDAE}

Gerrhosaurus flavigularis Wiegmann, 1828 (Yellowthroated plated lizard)

This species occurs mostly in north-eastern parts of South Africa, with an apparently isolated southern population. In a recent revision of the entire genus, three well-structured clades were formed (i.e. eastern South Africa, northern South Africa and East Africa) and current research may split these populations (Bates et al. 2013). If this is the case, the southern population will keep the name G. flavigularis, which will make the Silaka NR material the most northern record. The species was observed at three of the six reserves surveyed.

Tetradactylus cf. fitzsimonsi (FitzSimons' long-tailed seps) Tetradactylus fitzsimonsi is restricted to only four QDUs in the Port Elizabeth area and one near George. The new records from Hluleka NR were found $600 \mathrm{~km}$ to the northeast of the $T$. fitzsimonsi distribution range. Identification of these specimens is based on FitzSimons (1943), with the main identifying characteristic being the lack of front limbs. Current genetic and morphometric work indicates that the Hluleka specimens might be a novel species related to T. fitzsimonsi (K. Tolley pers. comm., 14 July 2014). More than a century of herpetological studies in the Eastern Cape have failed to find any additional T. fitzimonsi records from the coastal Eastern Cape or the former Transkei. Furthermore, overlap of the distribution for T. fitzsimonsi and the congener, Tetradactylus africanus, is not clear. FitzSimons (1943) gives the distribution of T. africanus as Pondoland and northwards (i.e. northern Eastern Cape), but no recent records have been collected from this area (Bates 2014a, 2014b). The Ditsong National Museum of Natural History (TM 69067) houses a specimen of T. africanus from Msikaba River, near Mkambati NR (Bates 2014c). Additional surveys in coastal grassland along the Eastern Cape coastline will improve information on this species' distribution. For the purpose of this species inventory we consider the species as T. fitzsimonsi. 


\section{SCINCIDAE}

Acontias plumbeus Bianconii, 1849 (Giant legless skin)

This species represents the world's largest species of legless skink, with a maximum size recorded at $490 \mathrm{~mm}$, and is restricted to well-forested areas (Branch 1998). An isolated Eastern Cape population around East London shows a number of subtle morphological differences from northern populations (Bourquin \& Lambiris 1996), and possibly represents a new species (Branch 2002). Genetic studies are currently underway to determine the relationship of this population to northern populations (Daniels, in preparation). Its sister species, Acontias poecilus, is known from only five specimens in south-eastern KwaZulu-Natal (Bourquin \& Lambiris 1996) and only a single record from the Eastern Cape (Branch \& Haagner 1999), but may be present in Mkambati NR (Bauer 2014). Dwesa NR has a selection of preserved specimens on display for educational purposes, which includes a preserved $A$. plumbeus from the reserve (M. Burger pers. comm., 23 April 2014). This forms the basis of the present record in SARCA. We confirmed this distribution during the recent survey of Dwesa NR and reported a new distribution record for the Manubi SF area.

\section{Trachylepis homalocephala Wiegmann, 1828 (Red-sided skink)}

This species is found mostly in the Eastern Cape and Western Cape, with scattered populations in KwaZulu-Natal, Lesotho, the Free State, Mpumalanga and Limpopo. In the recent reptile atlas (Bates et al. 2014) there is a noticeable gap in the distribution from East London to the closest KwaZulu-Natal populations. This gap has been described as a biodiversity-poor gap due to negative environmental conditions (see main text). We recorded this species from all the reserves, indicating a sampling gap rather than a natural distribution gap. More surveys need to be conducted outside the reserves to determine the full extent of this species' distribution.

\section{CHAMAELEONIDAE}

Bradypodion caffer Boettger, 1889 (Pondo dwarf chameleon) Dwarf chameleons from Mkambati NR have been assigned to Bradypodion melanocephalum (Raw 2001; Tolley \& Burger 2007), given their morphological similarity to the species. They were therefore regarded as the population with the most southern distribution limit of the species (Tolley 2014a). In contrast, Raw (2001) regarded the Mkambati population as a new species. Recent molecular work on this population shows a close relationship to B. caffer, which may represent a grassland ecomorph (K. Tolley pers. comm., 14 July 2014). B. caffer is a forest-adapted species, whereas the Mkambati population was found only in natural grassland. Although morphological similarity might be expected within a species (i.e. amongst populations), structure is a known driver of morphological variation in dwarf chameleons habitat (Da Silva \& Tolley 2013; Hopkins \& Tolley 2011; Tolley 2014a). The grassland population of Mkambati most likely represents an ecomorph of $B$. caffer and is another example of ecological adaptation due to differences in habitat structure in this group. The forest and grassland ecomorphs should be considered as separate management units with regard to conservation and management. Despite a close genetic relationship, the two ecomorphs are distinct with regard to the morphological adaptations that allow them to persist in the different environments. Additional molecular and morphological work is required to better place the Mkambati population. B. caffer was also recorded from the forests at Silaka and Hluleka NRs (K. Tolley pers. comm., 14 July 2014) and has been classified as endangered (Tolley 2014b).

\section{Bradypodion kentanicum Hewitt, 1935 (Kentani dwarf chameleon)}

This species is restricted to coastal Scarp forest from Kentani in the south to Coffee Bay in the north (Tolley \& Burger 2007). It was represented in Dwesa NR and Manubi SF and has been assessed as vulnerable (Tolley 2014c).

\section{LEPTOTYPHLOPIDAE}

Leptotyphlops sylvicolus Broadley \& Wallach, 1997 (Forest thread snake)

The species is restricted to coastal moist forest (except for the Matatiele area, where they were found in grassland). Eastern Cape specimens differ morphologically from the main type and genetic differences indicate that a number of cryptic species exist. This is specifically the case with L. sylvicolus (Adalsteinsson et al. 2009). Further investigations of the isolated Eastern Cape specimens are needed and the populations may warrant special conservation concern. The species is currently regarded as data deficient (Alexander 2014a). It was collected from only two of the reserves surveyed and both represented new records for this species. At Mkambati NR, specimens were collected under rocks in gardens, but the surrounding vegetation type is grassland. In Hluleka NR, specimens were collected amongst the chalets, which are surrounded by coastal forest.

\section{PYTHONIDAE}

Python natalensis Smith, 1840 (Southern African python) Southern African pythons once extended to Port Alfred (Eastern Cape), but the last known specimen from this area was killed in Bathurst in 1927 (Broadley 1990; C. Vernon pers. comm. 13 November 2013). There are unconfirmed historical records of pythons killed in the Manubi or Dwesa Forest region (records seem to be unclear which forest) in 1845 (C. Vernon pers comm., 13 November 2013). In the early 1980s, specimens were re-introduced in the Andries Vosloo NR outside Grahamstown, but no follow-up work has been done on this population (Alexander 2014b; C. Vernon pers. comm., 13 November 2013). Anecdotal records exist for Mkambati NR (Burger 1996; De Villiers \& Costello 2013), as well as a single photographic record by ECPTA staff (see Figure 4C). The occurrence of $P$. natalensis in Mkambati NR is noteworthy, given that almost nothing has been recorded regarding python distribution in the former Transkei region and this is the only recent record for the Eastern Cape. 


\section{LAMPROPHIIDAE}

Amblyodipsas concolor Smith, 1849 (KwaZulu-Natal purple-glossed snake)

This is a fossorial species restricted to moist forested areas in the eastern and northern parts of southern Africa, feeding mostly on other snakes and lizards. This cryptic species can easily be confused with sympatric Amblyodipsas polylepis, Macrelaps microlepidotus and Atractaspis bibronii, which occur further north. They differ from the latter two as they do not have preocular scales, but do have paired subcaudals and divided anal scales (Broadley 1990; Marais 2004). They are also differentiated from $A$. polylepis by having lower midbody scale counts (17 vs 19) (Broadley 1990; Marais 2004). Previously the only record for the Eastern Cape was based on a specimen from Mtumbane, Port St Johns area (Haagner 1994: TM 69016). We extend the species' distribution $120 \mathrm{~km}$ southwards to Manubi SF and add two additional new records south of Port St Johns (Hluleka and Dwesa NRs). No records of either A. polylepis or A. bibronii exist for the Eastern Cape and more surveys are needed in the most north-eastern parts of the Eastern Cape to confirm the presence of this species.

\section{Macrelaps microlepidotus Günther, 1863 (KwaZulu-Natal black snake)}

Macrelaps microlepidotus is a semi-fossorial snake that inhabits moist forest and feeds on frogs, lizards and other snakes (Marais 2004). Its distribution is restricted mainly to the coastal eastern parts of South Africa, with an inland expansion into the Amatole region (Eastern Cape) and the Escourt area (KwaZulu-Natal). It has previously been known from only seven QDUs in the Eastern Cape. Recently, the most inland Eastern Cape record was confirmed from the Katberg area and two new QDUs (one based on the collection from Dwesa NR during this study) were added in the Eastern Cape (Conradie, Venter \& Nicolau 2012). We provide another new locality (Manubi SF), further indicating continuous distribution along the east coast of the Transkei. Owing to habitat destruction this species is rated as near threatened (Bates et al. 2014).

\section{Psammophis brevirostris Peters, 1881 (Short-snouted grass snake)}

This species occurs mostly in the northern and eastern parts of South Africa, inhabiting grassland and savannah. It has previously been found only in three localities in the Eastern Cape (Bates et al. 2014; Branch \& Haagner 1999), with its southern distribution limit around Mpande Beach (3129CD: PEM R13694). We extend the distribution $100 \mathrm{~km}$ south to Manubi SF and add two additional new records for the Eastern Cape (Mkambati and Hluleka NRs). A recently donated specimen to the PEM collection expands the distribution of this species even further south to the Kei River mouth (PEM 20166).

\section{ELAPIDAE}

\section{Dendroaspis polylepis Günther, 1864 (Black mamba)}

Only two records exist for this species in the Eastern Cape, namely from Port St Johns (TM 21455) and Mkambati NR. The latter is based only on observational data (Burger 1996;
De Villiers \& Costello 2013). It is likely that this species will occur more widely in the north-eastern parts of the Eastern Cape. We found none during this study.

\section{COLUBRIDAE}

Thelotornis capensis capensis Smith, 1849 (south-eastern savannah vine-snake)

T. capensis capensis is an arboreal species that occurs in coastal thicket and savannah. The only record for the Eastern Cape is an anecdotal sighting by D. de Villiers (pers. comm., 23 April 2014). The specimen was sighted and photographed (photo could not be found) near the Msikaba River vulture colony in Mkambati NR (D. de Villiers pers. comm., 23 April 2014). This forms the basis of the SARCA record for the Eastern Cape (Marais 2014b) and has been listed in De Villiers and Costello (2013). The record needs to be confirmed and voucher specimens need to be collected.

\section{References for Appendix 1}

Adalsteinsson, S.A., Branch, W.R., Trape, S., Vitt, L.J \& Hedges, S.B., 2009 'Molecular phylogeny, classification, and biogeography of snakes of the family Leptotyphlopidae (Squamata, Scolecophidia)', Zootaxa 2244, 1-50.

Alexander, G.J., 2014a, 'Leptotyphlops sylvicolus Broadley \& Wallach, 1997', in M.F. Bates, W.R. Branch, A.M. Bauer, M. Burger, J. Marais, G.J. Alexander et al. (eds.), Atlas and red data list of the reptiles of South Africa, Lesotho and Swaziland, pp. 322-323, South African National Biodiversity Institute, Pretoria (Suricata series; $322-323,5$
no. 1$)$.

Alexander, G.J., 2014b, 'Python natalensis A. Smith, 1840' in M.F. Bates, W.R. Branch A.M. Bauer, M. Burger, J. Marais, G.J. Alexander et al. (eds.), Atlas and red data list of the reptiles of South Africa, Lesotho and Swaziland, p. 328, South African National Biodiversity Institute, Pretoria (Suricata series; no. 1).

Bates, M.F., 2014a, 'Tetradactylus africanus Gray, 1838', in M.F. Bates, W.R. Branch, A.M. Bauer, M. Burger, J. Marais, G.J. Alexander et al. (eds.), Atlas and red data list of the reptiles of South Africa, Lesotho and Swaziland, p. 231, South African National Biodiversity Institute, Pretoria (Suricata series; no. 1).

Bates, M.F., 2014b, 'Tetradactylus fitzsimonsi Hewitt 1915', in M.F. Bates, W.R. Branch, A.M. Bauer, M. Burger, J. Marais, G.J. Alexander et al. (eds.), Atlas and red data list of the reptiles of South Africa, Lesotho and Swaziland, p. 234, South African National Biodiversity Institute, Pretoria (Suricata series; no. 1).

Bates, M.F., 2014c, 'Geographical distributions: Tetradactylus africanus (Gray, 1838)', African Herp News 61(2), 35-36.

Bates, M.F., Branch, W.R., Bauer, A.M., Burger, M., Marais, J., Alexander, G.J. et al., 2014, Atlas and red data list of the reptiles of South Africa, Lesotho and Swaziland South African National Biodiversity Institute, Pretoria.

Bates, M.F., Tolley, K., Edwards, S., Davids, Z., Da Silva, J. \& Branch, W.R., 2013, 'A molecular phylogeny of the African plated lizards, genus Gerrhosaurus Wiegmann, 1828 (Squamata: Gerrhosauridae), with the description of two new genera', Zootaxa 3750(5), 465-493. http://dx.doi.org/10.11646/zootaxa.3750.5.3

Bauer, A.M., 2014, 'Acontias poecilus Bourquin \& Lambiris', in M.F. Bates, W.R. Branch, A.M. Bauer, M. Burger, J. Marais, G.J. Alexander et al. (eds.), Atlas and red data list of the reptiles of South Africa, Lesotho and Swaziland, pp. 249-250, South African National Biodiversity Institute, Pretoria (Suricata series; no. 1).

Bourquin, O. \& Lambiris, A.J.L., 1996, 'A new species of Acontias [c] uvier (Sauria: Scincidae) from southeastern KwaZulu-Natal, South Africa', Annals of the Transvaal Museum 36(17), 223-227.

Branch, W.R., 1998, Field guide to the snakes and other reptiles of Southern Africa, Struik, Cape Town

Branch, W.R., 2002, 'Terrestrial fauna', in 'N2 Wild Coast Toll Road between Durban and East London', environmental impact assessment report, CCA Environmental, Cape Town.

Branch, W.R., 2014, 'Lygodactylus capensis capensis A. Smith 1849', in M.F. Bates, W.R. Branch, A.M. Bauer, M. Burger, J. Marais, G.J. Alexander et al. (eds.), Atlas and red data list of the reptiles of South Africa, Lesotho and Swaziland, p. 118, South African National Biodiversity Institute, Pretoria(Suricata series; no. 1).

Branch, W.R. \& Haagner, G.V., 1999, 'Geographical distribution: Psammophis brevirostris and Acontias sp.: the value of road kills', African Herp News 30, 37-38.

Broadley, D.G., 1990, FitzSimons' snakes of Southern Africa, Jonathan Ball \& Ad. Donker, Parklands.

Burger, M., 1996, 'Report on a herp[e]tofaunal survey conducted in the former Transkei region', unpublished report, Ministry of Economic Affairs, Environment \& Tourism, Eastern Cape Nature Conservation.

Channing, A., Hillers, A., Lotters, M.O., Schick, S., Conradie, W., Rodder, D. et al., 2013a 'Taxonomy of the super-cryptic Hyperolius nasutus group of long reed frogs of Africa (Anura: Hyperoliidae), with descriptions of six new species', Zootaxa 3620 301-350. http://dx.doi.org/10.11646/zootaxa.3620.3.1 
Channing, A., Schmitz, A., Burger, M. \& Kielgast, J., 2013b, 'A molecular phylogeny of African Dainty Frogs, with the description of four new species (Anura:

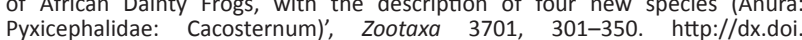
Pyxicephalidae: Cacosternum)'

Conradie, W., 2014, 'The king of the dwarves: a new cryptic species of Dainty Frog (Anura: Pyxicephalidae: Cacosternum) from the eastern Great Escarpment of South Africa', Zootaxa 3785(3), 438-452. http://dx.doi.org/10.11646/zootaxa.3785.3.6

Conradie, W., Venter, J.A. \& Nicolau, J.R., 2012, 'Geographical distribution: Macrelaps microlepidotus Günther, 1860', African Herp News 58, 19-21.

Da Silva, J.M. \& Tolley, K.A., 2013, 'Ecomorphological variation and sexual dimorphism in a recent radiation of dwarf chameleons (Bradypodion)', Biological Journal of the Linnean Society 109(1), 113-130. http://dx.doi.org/10.1111/bij.12045

De Villiers, D. \& Costello, J., 2013, Mkambati and the Wild Coast, 2nd edn., Div de Villiers and John Costello, Port St Johns.

Du Preez, L.H., 2004, 'Natalobatrachus bonbergi Hewitt and Methuen, 1913', in L.R. Minter, M. Burger, J.A. Harrison, H.H. Braack, P.J. Bishop \& D. Kloepfer (eds.), Atlas and red data book of the frogs of South Africa, Lesotho and Swaziland, pp. 246247, Smithsonian Institute, Washington, DC (SI/MAB Series; no. 9).

Feely, J.M., 2010, 'On the southeastern range limits of the Nile crocodile: a review of its past and present occurrences in the Eastern Cape and Western Cape, South Africa', South African Journal of Wildlife Research 40(2), 169-175. http://dx.doi. org/10.3957/056.040.0209

FitzSimons, V.F.M., 1930, 'Descriptions of new South African Reptilia and Batrachia, with distribution records of allied species in the Transvaal Museum collection', Annals of the Transvaal Museum 14, 20-48.

FitzSimons, V.F.M., 1943, 'The lizards of South Africa', Transvaal Museum Memoirs $1,1-528$.

Frost, D.R., 2014, Amphibian species of the world: An online reference, Version 6.0 , online database, viewed 24 June 2014, from http://research.amnh.org/ herpetology/amphibia/index.html, American Museum of Natural History, New York.

Haagner, G.V., 1994, 'Geographical distribution: Amblyodipsas concolor', African Herp News 21, 26.

Hopkins, K.P. \& Tolley, K.A., 2011, 'Morphological variation in the Cape Dwarf Chameleon (Bradypodion pumilum) as a consequence of spatially explicit habitat structure differences', Biological Journal of the Linnean Society 102(4), 878-888.

Laurent, R.F., 1941, 'Contribution à l'ostéologie et à la systématique des ranides africains, Première note [Contribution to the osteology and the systematics of African Ranidae, Primary notes]', Revue de Zoologie et de Botanique Africaines African Ranid
34, 74-96.

Marais, J., 2004, A complete guide to the snakes of Southern Africa, Struik, Cape Town.

Marais, J., 2014a, 'Crocodylus niloticus Laurenti, 1768, Nile Crocodile', in M.F. Bates, W.R. Branch, A.M. Bauer, M. Burger, J. Marais, G.J. Alexander et al. (eds.), Atlas and red list of of the reptiles of South Africa, Lesotho and Swaziland, pp. 87-88, .South African National Biodiversity Institute, Pretoria.

Marais, J., 2014b, 'Thelotornis capensis capensis A. Smith 1849', in M.F. Bates, W.R Branch, A.M. Bauer, M. Burger, J. Marais, G.J. Alexander et al. (eds.), Atlas and red data list of the reptiles of South Africa, Lesotho and Swaziland, p. 423, South African National Biodiversity Institute, Pretoria (Suricata series; no. 1).
Measey, G.J., 2011, Ensuring a future for South Africa's frogs: A strategy for conservation research, South African National Biodiversity Institute, Petoria (SANBI Biodiversity Series; no. 19).

Minter, L.R., 2004a, 'Breviceps bagginsi Minter, 2003', in L.R. Minter, M. Burger, J.A Harrison, H.H. Braack, P.J. Bishop \& D. Kloepfer (eds.), Atlas and red data book of the frogs of South Africa, Lesotho and Swaziland, pp. 174-175, Smithsonian Institute, Washington, DC (SI/MAB Series; no. 9).

Minter, L.R., 2004b. 'Breviceps mossambicus Peters, 1854', in L.R. Minter, M. Burger J.A. Harrison, H.H. Braack, P.J. Bishop \& D. Kloepfer (eds.), Atlas and red data Book of the Frogs of South Africa, Lesotho and Swaziland, pp. 184-186, Smithsonian Institute, Washington, DC (SI/MAB Series; no. 9).

Minter, L.R., Burger, M., Harrison, J.A., Braack, H.H., Bishop, P.J. \& Kloepfer, D., 2004, Atlas and red data book of the frogs of South Africa, Lesotho and Swaziland, Smithsonian Institute, Washington, DC (SI/MAB Series; no. 9).

Peinke, D. \& Gibisela, Z., 2013, 'Game census report 2013', unpublished report, Eastern Cape Parks and Tourism Agency, East London.

Pickersgill, M., 1996, 'A new subspecies of Afrixalus (Anura: Hyperoliidae) from KwaZulu-Natal, South Africa, with comments on its superspecies affinities', Durban Museum Novitates 21, 49-59.

Pooley, A.C., 1980, 'Crocodile research in Maputaland', in M.N. Bruton \& K.H. Cooper (eds.), Studies on the ecology of Maputaland, pp. 293-299, Wildlife Society of Southern Africa, Grahamstown.

Poynton, J.C., 1964, 'The amphibia of southern Africa: a faunal study', Annals of the Natal Museum 17, 1-334.

Raw, L.R.G., 2001, 'Revision of some dwarf chameleons (Sauria: Chamaleonidae: Bradypodion) from eastern South Africa', MSc dissertation, School of Botany and Zoology, University of Natal.

Tarrant, J., 2012, 'Conservation assessment of the threatened amphibians on KwaZulu-Natal, and a national assessment of the chytrid infection in South African threatened species', PhD thesis, School for Biological Sciences, North-West University.

Tolley, K., 2014a, 'Bradypodion melanocephalum (Gray, 1865 “1864”)', in M.F. Bates, W.R. Branch, A.M. Bauer, M. Burger, J. Marais, G.J. Alexander et al. (eds.), Atlas and red data list of the reptiles of South Africa, Lesotho and Swaziland, pp. 291292, South African National Biodiversity Institute, Pretoria (Suricata series; no. 1).

Tolley, K.A., 2014b, 'Bradypodion caffer Boettger, 1889', in M.F. Bates, W.R. Branch, A.M. Bauer, M. Burger, J. Marais, G.J. Alexander et al. (eds.), Atlas and red data list of the reptiles of South Africa, Lesotho and Swaziland, p. 288, South African National Biodiversity Institute, Pretoria (Suricata series; no. 1).

Tolley, K.A., 2014c, 'Bradypodion ketanicum Hewitt 1935', in M.F. Bates, W.R. Branch A.M. Bauer, M. Burger, J. Marais, G.J. Alexander et al. (eds.), Atlas and red data list of the reptiles of South Africa, Lesotho and Swaziland, pp. 290-291, South African National Biodiversity Institute, Pretoria (Suricata series; no. 1).

Tolley, K. \& Burger, M., 2007, Chameleons of Southern Africa, Struik, Cape Town.

Venter, J.A. \& Conradie, W., 2012, 'The amphibians and reptiles of Dwesa Nature Reserve: A report on a rapid biodiversity survey conducted in February 2012', unpublished report, Eastern Cape Parks and Tourism Agency, East London. 


\section{Appendix 2}

\section{List of all amphibian material from the Port Elizabeth Museum examined for the study}

\section{Amphibians}

Arthroleptis wahlbergii: Silaka NR (PEM A10548-10554), Hluleka NR (PEM A9967, 10001). Leptopelis natalensis: Mkambati NR (PEM A9565; PEM T434), Silaka NR (PEM A10588-10591), Hluleka NR (PEM A9979, 9980; PEM T497, 505), Dwesa NR (PEM T535, 541, 542), Manubi (PEM T640). Breviceps cf. bagginsi: Silaka NR (PEM A10565-10569). Breviceps verrucosus: Silaka NR (PEM A10570). Amietophrynus gutturalis: Mkambati NR (PEM A6908, 9553-9556), Silaka NR (PEM A10563, 10564; PEM T592), Hluleka NR (PEM A2141, 2142, 6942, 9970, 9971, 9978), Dwesa NR (PEM A10115, 10130; PEM T536, 545), Cape Morgan NR (PEM A10164, 10172). Amietophrynus rangeri: Mkambati NR (PEM A9557-9559), Hluleka NR (PEM A6936), Dwesa NR (PEM A3460, 6751, 10126, 10155), Manubi SF (PEM A10723, 10727, 10728), Cape Morgan NR (PEM A10165, 10175, 10177, 10178). Afrixalus spinifrons: Silaka NR (PEM A10555-10560; PEM T593, 632), Hluleka NR (PEM A9984, 9986). Hyperolius marmoratus verrucosus: Mkambati NR (PEM A6903, 6909, 6910, 95609563; PEM T428-431, 669), Silaka NR (PEM A10577-10580), Hluleka NR (PEM A2147-2151, 6924-6927, 9963, 9964, 9982, 9983, 9990, 9991), Dwesa NR (PEM A6753, 10116, 10120, 10124, 10125, 10136, 10141; PEM T539, 543), Manubi SF (PEM A10730, 10734, 10735; PEM T636, 637), Cape Morgan NR (PEM A10184, 10185; PEM T549). Hyperolius poweri: Mkambati NR (PEM A6911-6914, 9545, 9546, 11106, 11107; PEM T426, 427). Hyperolius pusillus: Silaka NR (PEM A10581, 10582), Hluleka NR (PEM A6928-6930, 9985, 9987-9989), Dwesa NR (PEM A10122, 10135, 10140, 10142, 10148, 10153; PEM T538), Manubi SF (PEM T638). Hyperolius semidiscus: Silaka NR (PEM A10583-10586), Hluleka NR (PEM A6939-6941, 99959997), Dwesa NR (PEM A10111-11014, 10117-10119, 10121, 10137). Kassina senegalensis: Mkambati NR (PEM A9564; PEM T432, 433, 665, 667), Silaka NR (PEM A10587), Hluleka NR (PEM A9962, 9969, 9973, 9974, 9977), Dwesa NR (PEM T537, 546), Manubi SF (PEM T639), Cape Morgan NR (PEM A10170, 10174, 10186, 10187). Phrynobatrachus natalensis: Mkambati NR (PEM A6917, 9566; PEM T440, 441, 669), Silaka NR (PEM A10595-10597; PEM T594), Hluleka NR (PEM A9959-9961, 9965, 9968; PEM T506, 507), Dwesa NR (PEM A8194-8196, 10127, 10129, 10145, 10151; PEM T540), Manubi SF (PEM A10733), Cape Morgan NR (PEM A10166-10168). Xenopus laevis: Mkambati NR (PEM A9573, 9574; PEM T737), Silaka NR (PEM T599), Hluleka NR (PEM A9975, 9976), Dwesa NR (PEM 10138), Manubi SF (PEM A10731, 10736), Cape Morgan NR (PEM A10179). Ptychadena oxyrhynchus: Mkambati NR (PEM A9567; PEM T443-446), Silaka NR (PEM A10598-10601), Hluleka NR (PEM A2143, 9981, 9994), Dwesa NR (PEM A10139; PEM T544), Cape Morgan NR (PEM A10182). Ptychadena porosissima: Mkambati NR (PEM A9568-9570; PEM T442). Amietia quecketti: Mkambati NR (PEM A7049-7053, 9547-9552; PEM T438, 439), Silaka NR (PEM A10561, 10562), Hluleka NR (PEM A2144-2146, 7062, 9966, 9998; PEM T509), Dwesa NR (PEM A3953-3955, 10108,
10123, 10128, 10132-10134, 10147; PEM T588), Manubi SF (PEM A10729, 10732; PEM T633), Cape Morgan NR (PEM A10180, 10181, 10183). Cacosternum nanum: Silaka NR (PEM A10571-10576; PEM T595, 596), Hluleka NR (PEM A9999, 10000; PEM T495, 496, 499, 503, 508), Dwesa NR (PEM A10143, 10144, 10146, 10149, 10150, 10152, 10154), Manubi SF (PEM T634, 635), Cape Morgan NR (PEM A10109, 10110, 10163). Natalobatrachus bonebergi: Silaka NR (PEM A1059210594; PEM T597), Hluleka NR (PEM A9992, 9993; PEM T502, 504, 510), Manubi SF (PEM A10724, 10725; PEM T641). Strongylopus fasciatus: Mkambati NR (PEM A6918), Silaka NR (PEM A10602; PEM T598), Dwesa NR (PEM A4091, 10131), Manubi SF (PEM A10726), Cape Morgan NR (PEM A10169, 10171, 10173, 10176, 10188). Strongylopus grayii: Mkambati NR (PEM A6922). Tomopterna natalensis: Mkambati NR (PEM A6915, 6916, 9571, 9572; PEM T435, 436), Hluleka NR (PEM A9972, 10002).

\section{Reptiles}

Crocodylus niloticus: Dwesa NR (ECPTA). Pelomedusa galeata: Mkambati NR (PEM R19172), Silaka NR (ECPTA), Hluleka NR (ECPTA), Dwesa NR (PEM R19787, 19790), Manubi SF (PEM R20297). Afroedura pondolia: Mkambati NR (PEM R9711, 12031, 19152), Hluleka NR (PEM R13377-13379, 19427, 19435, 19436), Dwesa NR (PEM R13327, 13328, 13448, 13842, 13857, 19783, 19799, 19803). Hemidactylus mabouia: Mkambati NR (PEM R9710, 13367, 19155, 19156), Silaka NR (PEM R20140-20144), Hluleka NR (PEM R13375, 13376, 19426, 19440), Dwesa NR (PEM R19798, 19804), Manubi SF (PEM R20290), Cape Morgan NR (PEM R19863, 19864, 19873). Pachydactylus maculatus: Silaka NR (PEM R20145, 20146), Manubi SF (PEM R20291), Cape Morgan NR (PEM A19870). Agama atra: Manubi ST (PEM R13008, 20296), Cape Morgan NR (PEM R19872). Material: Mkambati NR (PEM R13370, 19153, 19154, 20686), Silaka NR (PEM R20133), Manubi ST (PEM R20282, 20283), Cape Morgan NR (PEM R19874, 19877). Bradypodion caffer: Mkambati NR (PEM R20685, 20687-20689). Bradypodion ketanicum: Dwesa NR (PEM R5503, 5505, 17101, 17102, 19789, 19800), Manubi SF (PEM R16616, 16711). Acontias plumbeus: Dwesa NR (PEM R19811), Manubi SF (PEM R20279). Trachylepis homalocephala: Mkambati NR (PEM R19157), Silaka NR (PEM R20151), Hluleka NR (PEM R19433), Dwesa NR (PEM R19807), Manubi SF (PEM R20299, 20300), Cape Morgan NR (PEM R19868, 19871). Trachylepis varia: Mkambati NR (PEM R13368, 19158-19161), Silaka NR (PEM R20149, 20150), Hluleka NR (PEM R19428, 19434, 19452), Dwesa NR (PEM R13779, 19788, 19801), Manubi SF (PEM R20301, 20302), Cape Morgan NR (PEM R19875, 19876). Tropidosaura montana natalensis: Mkambati NR (PEM R19173). Chamaesaura anguina anguina: Hluleka NR (PEM R19443), Dwesa NR (PEM R19802). Gerrhosaurus flavigularis: Silaka NR (PEM R20138, 20139), Dwesa NR (PEM R19797, 19809, 19810), Cape Morgan NR (PEM R19869). Tetradactylus cf. fitzsimonsi: Hluleka NR (PEM R19424, 19425, 19453, 19456). Varanus niloticus: Mkambati NR (PEM R20864), Silaka NR (ECPTA), Hluleka NR (PEM R19451), Dwesa NR (PEM R13329, 19808), Cape Morgan NR (ECPTA). Leptotyphlops sylvicolus: Mkambati NR (PEM R18079, 19164, 19165), 
Hluleka NR (PEM R19439). Afrotyphlops bibronii: Silaka NR (PEM R20130-20132), Hluleka NR (PEM R19429, 19430, 19438), Dwesa NR (PEM R13693, 13836, 19805), Manubi SF (PEM R20280, 20281). Crotaphopeltis hotamboeia: Mkambati NR (PEM R19163), Hluleka NR (PEM R19444), Dwesa NR (PEM R19796), Manubi SF (PEM R20287) Dasypeltis inornata: Hluleka NR (PEM R19445), Dwesa NR (PEM R13692). Dispholidus typus typus: Hluleka NR (PEM R19447, 19448), Dwesa NR (PEM R13725, 19785). Philothamnus hoplogaster: Hluleka NR (PEM R13690). Philothamnus natalensis occidentalis: Mkambati NR (PEM R19167, 19168), Silaka NR (PEM R20147, 20148), Cape Morgan NR (PEM A19878). Python natalensis: Mkambati NR (ECPTA). Amblyodipsas concolor: Hluleka NR (PEM R19437), Dwesa NR (PEM R19795), Manubi SF (PEM R20284, 20285). Boaedon capensis:
Mkambati NR (PEM R13369), Silaka NR (PEM R20135), Hluleka NR (PEM R19454, 19455). Duberria lutrix lutrix: Silaka NR (PEM R20137), Hluleka NR (PEM R19431, 19432), Dwesa NR (PEM R13724), Manubi SF (PEM R20288, 20289), Cape Morgan NR (PEM R19866). Lycodonomorphus rufulus: Dwesa NR (PEM R19792, 19793), Manubi SF (PEM R20292, 20295). Lycophidion capense: Mkambati NR (PEM R19166), Dwesa NR (PEM R19794). Macrelaps microlepidotus: Dwesa NR (PEM R19786, 19791), Manubi SF (PEM R20294, 20295). Psammophis brevirostris: Mkambati NR (PEM R19169-19171), Hluleka NR (PEM R19446), Manubi SF (PEM R20298). Bitis arietans: Silaka NR (PEM R20134). Causus rhombeatus: Mkambati NR (PEM R19162), Silaka NR (PEM R20136), Hluleka NR (PEM R19449, 19450), Dwesa NR (PEM R19806), Manubi SF (PEM R20286), Cape Morgan NR (PEM R13714, 19865, 19867). 


\section{Appendix 3}

\section{Additional records used in compiling the final checklist of amphibians and reptiles of the Wild Coast reserves}

TM, Ditsong National Museum of Natural History (formerly Transvaal Museum); CAS, California Academy of Science; DMR, Durban Natural Science Museum.

\section{Amphibians}

Arthroleptis wahlbergii: Hluleka NR (SAFAP 116500, 141009), Silaka NR (SAFAP 14100). Leptopelis natalensis: Dwesa NR (SAFAP 116240), Hluleka NR (SAFAP 141006), Mkambati NR (SAFAP 116162, 116226), Silaka NR (SAFAP 116243; CAS 11606, 211607). Breviceps bagginsi: Mkambati NR (SAFAP 116148, 116742, 117408), Silaka NR (SAFAP 116147). Breviceps verrucosus: Mkambati NR (SAFAP 116743, 117409), Silaka NR (SAFAP 116146). Amietophrynus gutturalis: Hluleka NR (SAFAP 141004), Mkambati NR (SAFAP 116154, 116161, 116223, 116744), Silaka NR (SAFAP 116247, 140996). Amietophrynus rangeri: Cape Morgan NR (SAFAP 115819, 115821), Dwesa NR (SAFAP 117285). Hyperolius marmoratus verrucosus: Cape Morgan NR (SAFAP 115817, 115822), Dwesa NR (SAFAP 117289, 116238), Hluleka NR (CAS 21162, CAS 211611), Manubi SF (SAFAP 115772), Mkambati NR (SAFAP 116157, 116164, 116224, 116745), Silaka NR (SAFAP 116244, 140998). Hyperolius poweri: Mkambati NR (SAFAP 116158, 116746). Hyperolius semidiscus: Cape Morgan NR (SAFAP 115823), Hluleka NR (CAS 211609, 211610), Mkambati NR (SAFAP 116165), Silaka NR (SAFAP 115618, 116245).
Kassina senegalensis: Cape Morgan NR (SAFAP 115825), Manubi SF (SAFAP 115774), Mkambati NR (SAFAP 116155). Phrynobatrachus natalensis: Cape Morgan NR (SAFAP 115818), Mkambati NR (SAFAP 116160, 116163, 116227), Silaka NR (CAS 211604, 211605,). Xenopus laevis: Dwesa NR (SAFAP 116219, 117460). Ptychadena oxyrhynchus: Mkambati NR (SAFAP 116156, 116220, 117415), Silaka NR (SAFAP 116242). Ptychadena porosissima: Mkambati NR (SAFAP 116221, 117416). Amietia quecketti: Cape Morgan NR (SAFAP 115740), Dwesa NR (SAFAP 127053), Hluleka NR (SAFAP 141005), Mkambati NR (SAFAP 116748, 117417, 117418, 117458, 117459), Silaka NR (SAFAP 115616, 140999). Cacosternum boettgeri: Mkambati NR (SAFAP 11652). Cacosternum nanum: Cape Morgan NR (SAFAP 115820, 115824), Hluleka NR (SAFAP 117439), Manubi SF (SAFAP 115773), Mkambati NR (SAFAP 116149, 116152, 116166). Natalobatrachus bonebergi: Silaka NR (SAFAP 116246), Dwesa NR (SAFAP 116239). Strongylopus fasciatus: Dwesa NR (SAFAP 127052), Hluleka NR (SAFAP 141007), Mkambati NR (SAFAP 116153, 116222). Tomopterna natalensis: Mkambati NR (SAFAP 116150, 116159, 116217, 116225).

\section{Reptiles}

Afroedura pondolia: Silaka NR (TM 76520), Dwesa NR (TM 69607-69621). Hemidactylus mabouia: Manubi SF (TM 69605, 69606). Agama atra: Mkambati NR (DMR1124). Bradypodion caffer: Silaka NR (SARCA 100520, 100521). Bradypodion ketanicum: Dwesa NR (SARCA 100721). Acontias plumbeus: Dwesa NR (SARCA 129704). Dasypeltis inornata: Hluleka NR (SARCA 1576). Dispholidus typus: Dwesa NR (SARCA 4373). Lycophidion capense: Mkambati NR (DMR1107). 


\section{Appendix 4}

TABLE 1-A4: A summary of the locations, habitats and trapping dates where drift fence with pitfall or funnel combinations were set in the six protected areas along the Wild Coast, Eastern Cape, South Africa.

\begin{tabular}{|c|c|c|c|c|c|c|c|}
\hline Protected area & Trap ID & Coordinates & & Habitat description & Plate & Trapping dates & Trap days \\
\hline Cape Morgan & $\mathrm{CM} 1 / 12$ & $32.70232 \mathrm{~S}$ & $28.35091 \mathrm{E}$ & $\begin{array}{l}\text { Swamp forest/wetland: dense ferns, sedges } \\
\text { and reeds; soil very wet }\end{array}$ & A & 26 Mar. - 02 Apr. 2012 & $6(P=24 ; F=36)$ \\
\hline Cape Morgan & $\mathrm{CM} 2 / 12$ & $32.70141 \mathrm{~S}$ & $28.34971 \mathrm{E}$ & $\begin{array}{l}\text { Coastal grassland with bushclumps: grazed, } \\
\text { recently burned coastal grassland next to } \\
\text { bushclump with palms and Acacia sp. trees }\end{array}$ & B & 26 Mar. - 02 Apr. 2012 & $6(P=24 ; F=36)$ \\
\hline Cape Morgan & $\mathrm{CM} 3 / 12$ & $32.69476 \mathrm{~S}$ & $28.36074 \mathrm{E}$ & $\begin{array}{l}\text { Thicket drainage line with deep and muddy } \\
\text { black soils }\end{array}$ & C & 26 Mar. - 02 Apr. 2012 & $6(P=24 ; F=36)$ \\
\hline Cape Morgan & $\mathrm{CM} 4 / 12$ & $32.69953 \mathrm{~S}$ & $28.35802 \mathrm{E}$ & $\begin{array}{l}\text { Dune forest and tall tree forest close to office } \\
\text { complex }\end{array}$ & D & 26 Mar. - 02 Apr. 2012 & $6(P=24 ; F=36) 9)$ \\
\hline Cape Morgan & $\mathrm{CM} 5 / 12$ & $32.69156 \mathrm{~S}$ & $28.34887 \mathrm{E}$ & $\begin{array}{l}\text { Coastal grassland with Acacia sp. thicket edge } \\
\text { in Morgans Bay commonage }\end{array}$ & $\mathrm{E}$ & 27 Mar. - 02 Apr. 2012 & $5(P=20 ; F=30)$ \\
\hline Cape Morgan & $\mathrm{CM} 6 / 12$ & $32.70753 \mathrm{~S}$ & $28.34679 \mathrm{E}$ & Dune forest on sea side of secondary dune & $\mathrm{F}$ & 27 Mar. - 02 Apr. 2012 & $5(P=20 ; F=30)$ \\
\hline Manubi & $\mathrm{MA01/13}$ & $32.44096 \mathrm{~S}$ & $28.604466 \mathrm{E}$ & $\begin{array}{l}\text { Wetland with some small Eucalyptus sp. trees, } \\
\text { many old Eucalyptus tree (died from ring } \\
\text { barking); Scarp forest }\end{array}$ & G & 18-27 Feb. 2013 & $9(P=36 ; F=54)$ \\
\hline Manubi & $\mathrm{MA02/13}$ & $32.44416 \mathrm{~S}$ & $28.59796 \mathrm{E}$ & $\begin{array}{l}\text { Old, tall forest, minimal undergrowth; Scarp } \\
\text { forest }\end{array}$ & $\mathrm{H}$ & 18-27 Feb. 2013 & $9(P=36 ; F=54)$ \\
\hline Manubi & $\mathrm{MA03/13}$ & $32.44853 \mathrm{~S}$ & $28.59672 \mathrm{E}$ & $\begin{array}{l}\text { Old, tall forest, slightly more open canopy, } \\
\text { many small Pittosporum viridiflorum in } \\
\text { undergrowth; Scarp forest }\end{array}$ & 1 & 18-27 Feb. 2013 & $9(P=36 ; F=54)$ \\
\hline Manubi & $\mathrm{MA04/13}$ & $31.65949 \mathrm{~S}$ & $29.29955 \mathrm{E}$ & $\begin{array}{l}\text { Palm mosaic, short, overgrazed grassland; } \\
\text { Transkei coastal belt }\end{array}$ & J & 18-27 Feb. 2013 & $9(P=36 ; F=54)$ \\
\hline Manubi & $\mathrm{MA04/13}$ & $31.65103 \mathrm{~S}$ & $29.51192 \mathrm{E}$ & $\begin{array}{l}\text { Dune forest; low, fairly open canopy - } \\
\text { Subtropical dune thicket }\end{array}$ & K & 18-27 Feb. 2013 & $9(P=36 ; F=54)$ \\
\hline Manubi & $\mathrm{MA04/13}$ & $31.65531 \mathrm{~S}$ & $29.50457 \mathrm{E}$ & $\begin{array}{l}\text { Ecotone - coastal scrub/grassland. P4 arm } \\
\text { in grass, P3 arm on boundary and P1 arm in } \\
\text { Acacia sp. scrub; Subtropical dune thicket/ } \\
\text { subtropical seashore vegetation }\end{array}$ & $\mathrm{L}$ & 18-27 Feb. 2013 & $9(P=36 ; F=54)$ \\
\hline Dwesa & $\mathrm{D} 1 / 12$ & $32.30278 \mathrm{~S}$ & $28.83614 \mathrm{E}$ & $\begin{array}{l}\text { Coastal dune forest, on vegetated secondary } \\
\text { dune; Indian ocean coastal belt }\end{array}$ & M & 05-15 Feb. 2012 & $10(P=39 ; F=59)$ \\
\hline Dwesa & $\mathrm{D} 2 / 12$ & $32.28365 \mathrm{~S}$ & $28.83591 \mathrm{E}$ & Riverine forest, on Kobolo river; Scarp forest & $\mathrm{N}$ & 05-15 Feb. 2012 & $10(P=38 ; F=58)$ \\
\hline Dwesa & $\mathrm{D} 3 / 12$ & $32.28792 \mathrm{~S}$ & $28.86794 \mathrm{E}$ & $\begin{array}{l}\text { Short coastal grassland with scattered Cypress } \\
\text { sp. and a small pond; Indian ocean coastal belt }\end{array}$ & 0 & 06-15 Feb. 2012 & $9(P=36 ; F=54)$ \\
\hline Dwesa & $\mathrm{D} 4 / 12$ & $32.28304 \mathrm{~S}$ & $28.86469 \mathrm{E}$ & $\begin{array}{l}\text { Cymbopogon sp. tall and wet grassland on } \\
\text { edge of wetland and riparian forest; Indian } \\
\text { ocean coastal belt }\end{array}$ & $P$ & 06-15 Feb. 2012 & $9(P=36 ; F=54)$ \\
\hline Dwesa & $\mathrm{D} 5 / 12$ & $32.28584 \mathrm{~S}$ & $28.85278 \mathrm{E}$ & $\begin{array}{l}\text { Dry, recently burned (< } 12 \text { months) grassland; } \\
\text { Indian ocean coastal belt }\end{array}$ & Q & 06-15 Feb. 2012 & $9(P=35 ; F=53)$ \\
\hline Dwesa & $\mathrm{D} 6 / 12$ & $32.27626 \mathrm{~S}$ & $28.84885 \mathrm{E}$ & Mature Scarp forest & $\mathrm{R}$ & 06-15 Feb. 2012 & $9(P=34 ; F=51)$ \\
\hline Hluleka & $\mathrm{HH} 01 / 10 / 11$ & $31.82097 \mathrm{~S}$ & $29.29845 \mathrm{E}$ & $\begin{array}{l}\text { Tall, wet Cymbopogon plurinodus and Cyprus } \\
\text { sp. grassland adjacent to Acacia karoo } \\
\text { bushclump; edge of Scarp forest in Transkei } \\
\text { coastal belt vegetation type }\end{array}$ & $\mathrm{s}$ & 20-28 Oct. 2011 & $8(P=31 ; F=46)$ \\
\hline Hluleka & $\mathrm{HH} 02 / 10 / 11$ & $31.81784 \mathrm{~S}$ & $29.29799 \mathrm{E}$ & $\begin{array}{l}\text { Riverine forest infested with Cestrum } \\
\text { laevigatum; Scarp forest in Transkei coastal } \\
\text { belt vegetation type }\end{array}$ & $\mathrm{T}$ & 21-28 Oct. 2011 & $7(P=29 ; F=43)$ \\
\hline Hluleka & $\mathrm{HH} 03 / 10 / 11$ & $31.81806 \mathrm{~S}$ & $29.30017 \mathrm{E}$ & Tall, mature Scarp forest & U & 21-28 Oct. 2011 & $7(P=28 ; F=42)$ \\
\hline Hluleka & $\mathrm{HH} 04 / 10 / 11$ & $31.82822 \mathrm{~S}$ & $29.29682 \mathrm{E}$ & $\begin{array}{l}\text { Short coastal grassland; Transkei coastal belt } \\
\text { vegetation type }\end{array}$ & v & 21-28 Oct. 2011 & $7(P=28 ; F=42)$ \\
\hline Hluleka & $\mathrm{HH} 05 / 10 / 11$ & $31.83141 \mathrm{~S}$ & $29.29762 \mathrm{E}$ & $\begin{array}{l}\text { Tall, dry Cymbopogon plurinodus grassland } \\
\text { adjacent to dune forest in Transkei coastal belt } \\
\text { vegetation type }\end{array}$ & W & 21-28 Oct. 2011 & $7(P=28 ; F=41)$ \\
\hline Hluleka & HH06/10/11 & $31.82822 \mathrm{~S}$ & $29.29682 \mathrm{E}$ & $\begin{array}{l}\text { In Millettia grandis forest stand with Acacia } \\
\text { sp. and Gymnosporia buxifolia; Transkei } \\
\text { coastal belt vegetation type }\end{array}$ & $x$ & 21-28 Oct. 2011 & $7(P=27 ; F=41)$ \\
\hline Silaka & SIL 01/12 & $31.6501 \mathrm{~S}$ & $29.505013 \mathrm{E}$ & $\begin{array}{l}\text { Old forest; tall canopy with minimal ground } \\
\text { cover. Adjacent to large stream }\end{array}$ & Y & 29 Sept. - 06 Oct. 2012 & $8(P=32 ; F=48)$ \\
\hline Silaka & SIL 02/12 & $31.6501 \mathrm{~S}$ & $29.505013 \mathrm{E}$ & $\begin{array}{l}\text { Coastal grassland, tall grass; predominantly } \\
\text { Hiperenia }\end{array}$ & z & 29 Sep-06 Oct 2012 & $8(P=32 ; F=48)$ \\
\hline Silaka & SIL 03/12 & $31.65779 \mathrm{~S}$ & $29.50323 \mathrm{E}$ & $\begin{array}{l}\text { Floodplain, very thick grass component; } \\
\text { mainly Kikuyu. Adjacent to small stream, not } \\
\text { permanently flowing }\end{array}$ & $A A$ & 29 Sept. - 06 Oct. 2012 & $8(P=32 ; F=48)$ \\
\hline Silaka & SIL 04/12 & $31.65895 \mathrm{~S}$ & $29.50165 \mathrm{E}$ & $\begin{array}{l}\text { Short grassland; dry, warm, north-east-facing } \\
\text { slope. Gravelly soil }\end{array}$ & $A B$ & 29 Sept. - 06 Oct. 2012 & $8(P=32 ; F=48)$ \\
\hline Silaka & SIL 05/12 & $31.65103 \mathrm{~S}$ & $29.51192 \mathrm{E}$ & $\begin{array}{l}\text { Dry forest, low canopy and minimal ground } \\
\text { cover }\end{array}$ & $A C$ & 29 Sept. - 06 Oct. 2012 & $7(P=28 ; F=42)$ \\
\hline Silaka & SIL 06/12 & $31.65531 \mathrm{~S}$ & $29.50457 \mathrm{E}$ & $\begin{array}{l}\text { Ecotone - Forest/grassland; P4 arm in grass, } \\
\text { P3 arm on forest boundary and P2 arm in } \\
\text { forest }\end{array}$ & $A D$ & 29 Sept. - 06 Oct. 2012 & $7(P=28 ; F=42)$ \\
\hline
\end{tabular}


TABLE 1-A4 (Continues...): A summary of the locations, habitats and trapping dates where drift fence with pitfall or funnel combinations were set in the six protected areas along the Wild Coast, Eastern Cape, South Africa.

\begin{tabular}{|c|c|c|c|c|c|c|c|}
\hline Protected area & Trap ID & Coordinates & & Habitat description & Plate & Trapping dates & Trap days \\
\hline Mkambati & MKFT 1 & $31.28984 \mathrm{~S}$ & $29.98994 \mathrm{E}$ & $\begin{array}{l}\text { Gwe-gwe forest: Scarp forest vegetation type } \\
\text { patch of } \pm 7.76 \text { ha }\end{array}$ & $\mathrm{AE}$ & 07-13 Feb. 2011 & $6(P=25 ; F=37)$ \\
\hline Mkambati & MKFT 2 & $31.27716 \mathrm{~S}$ & $29.98765 \mathrm{E}$ & $\begin{array}{l}\text { Forest patch: Very small Scarp forest clump } \\
\text { surrounded by Cymbopogon validus-Digitaria } \\
\text { natalensis medium grassland community }\end{array}$ & $\mathrm{AF}$ & 08-13 Feb. 2011 & $5(P=20 ; F=31)$ \\
\hline Mkambati & MKFT 3 & $31.27783 \mathrm{~S}$ & $30.00504 \mathrm{E}$ & $\begin{array}{l}\text { Burned grassland: Recently burned Tristachya } \\
\text { leucothrix-Loudetia simplex short grassland } \\
\text { community. Between wetland and sandstone } \\
\text { outcrops. Pondoland-Ugu Sandstone Coastal } \\
\text { Sourveld vegetation type }\end{array}$ & AG & 07-13 Feb. 2011 & $6.00(P=24 ; F=36)$ \\
\hline Mkambati & MKFT 4 & $31.27613 \mathrm{~S}$ & $30.02296 \mathrm{E}$ & $\begin{array}{l}\text { Coastal grassland: Themeda triandra- } \\
\text { Centella asiatica dwarf grassland community. } \\
\text { Pondoland-Ugu Sandstone Coastal Sourveld } \\
\text { vegetation type }\end{array}$ & $\mathrm{AH}$ & 07-13 Feb. 2011 & $6(P=24 ; F=36)$ \\
\hline Mkambati & MKFT 5 & $31.26084 \mathrm{~S}$ & $30.03824 \mathrm{E}$ & $\begin{array}{l}\text { Mosquito beach: Cymbopogon validus } \\
\text { and Digitaria natalensis medium grassland } \\
\text { community. Pondoland-Ugu Sandstone } \\
\text { Coastal Sourveld vegetation type }\end{array}$ & $\mathrm{Al}$ & 08-13 Feb. 2011 & $5(P=20 ; F=30)$ \\
\hline
\end{tabular}



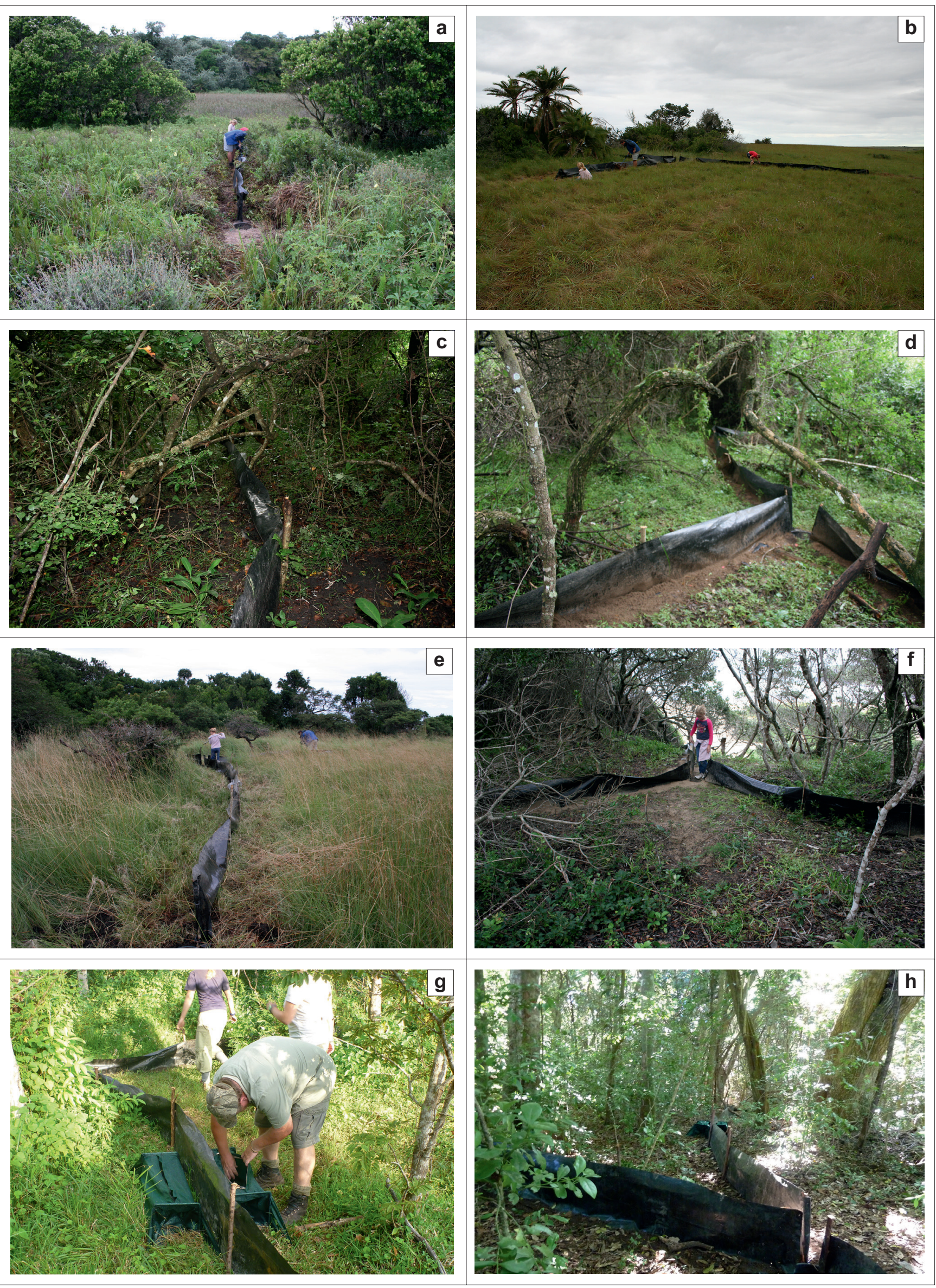

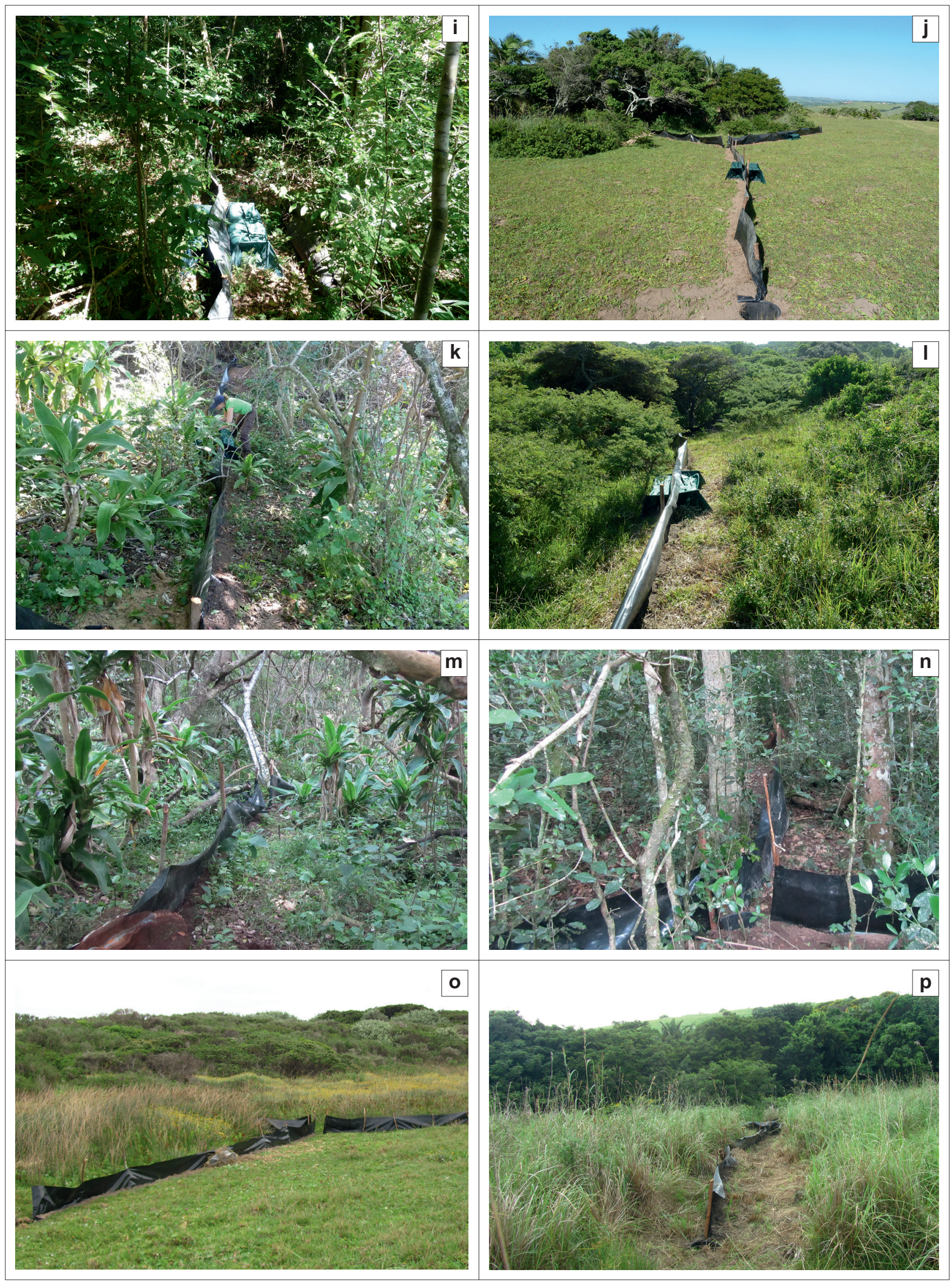

FIGURE 1-A4 (Continues...): (a-ai) Habitat type and trap layout of the respective trap sites surveyed during this study. 

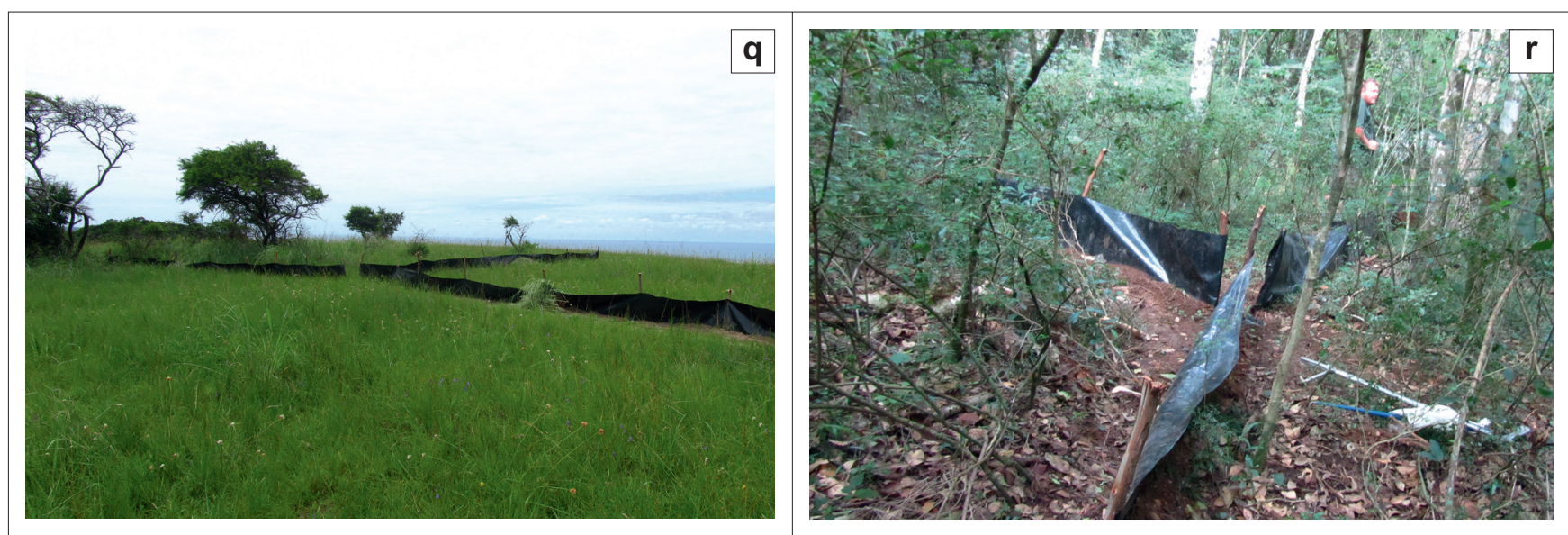

$\mathbf{S}$
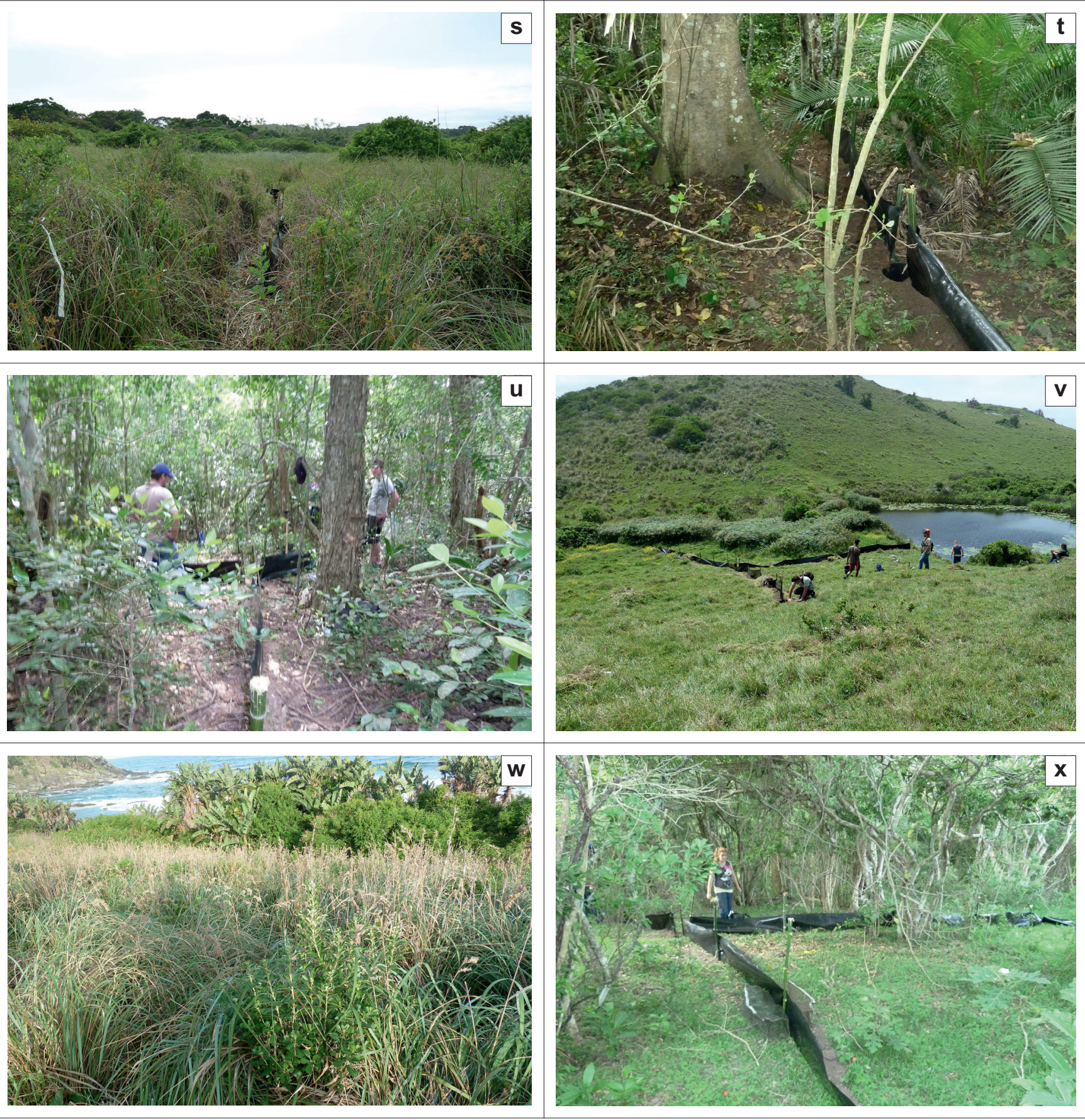

Source: Jan A. Venter

FIGURE 1-A4 (Continues...): (a-ai) Habitat type and trap layout of the respective trap sites surveyed during this study. 

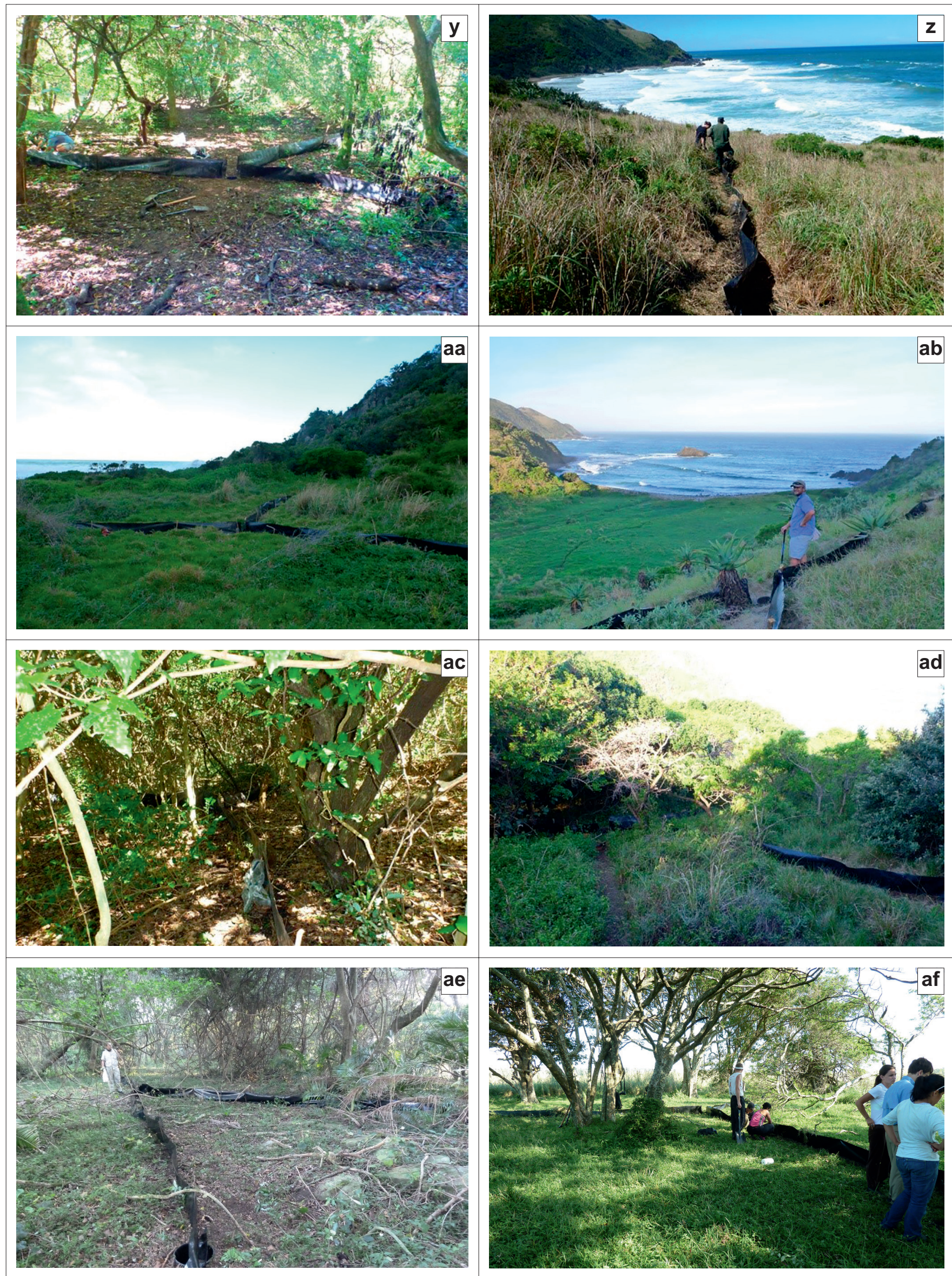

Source: Jan A. Venter

FIGURE 1-A4 (Continues...): (a-ai) Habitat type and trap layout of the respective trap sites surveyed during this study. 

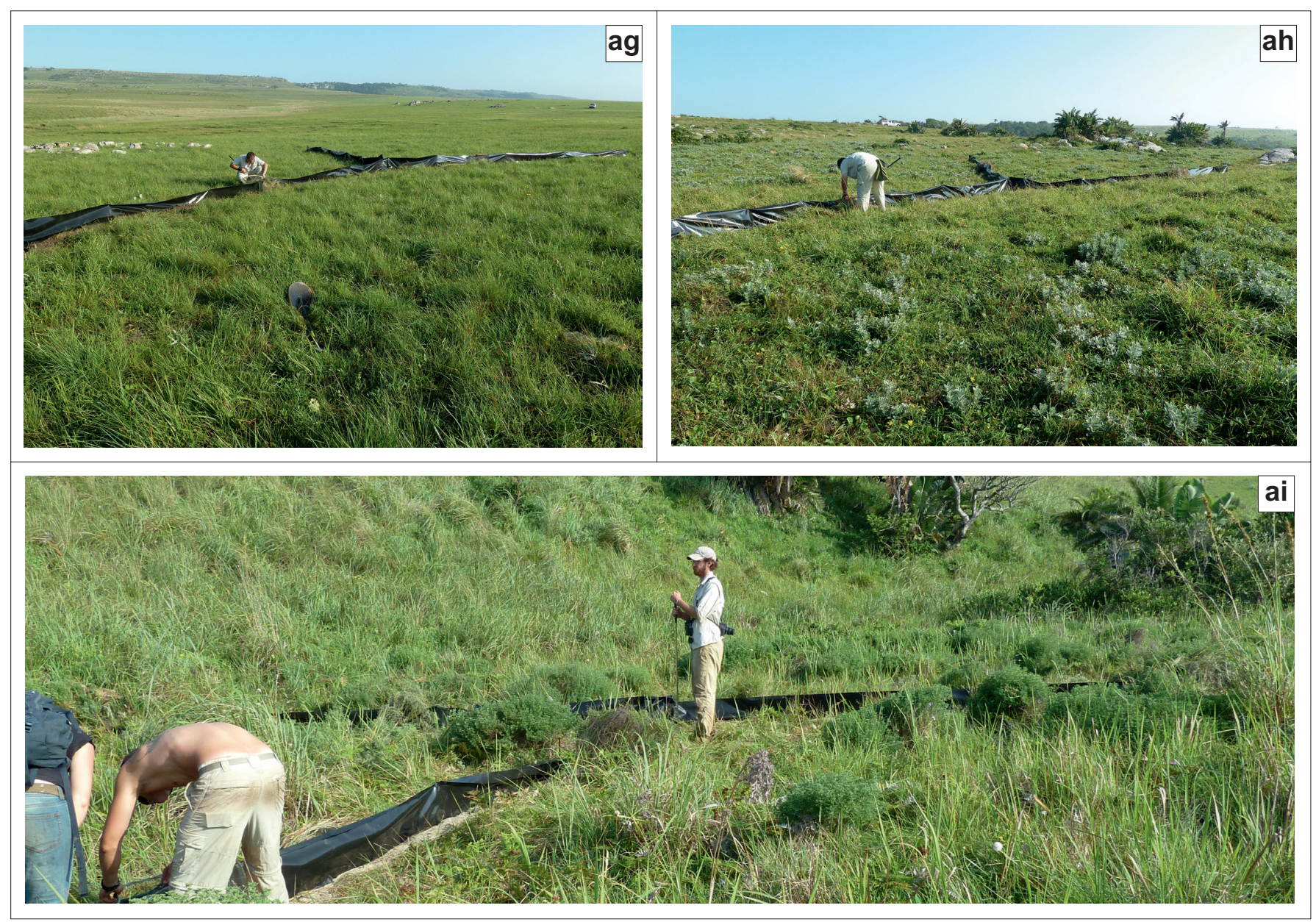

Source: Jan A. Venter

FIGURE 1-A4 (Continues...): (a-ai) Habitat type and trap layout of the respective trap sites surveyed during this study. 